\title{
Mentoring through the Transitions: Voices on the Verge
}

Edited by Mary L. Crowe and Bessie Guerrant 
Copyright $(02018$ Council on Undergraduate Research

All rights reserved. No part of this book may be reproduced or distributed in any form or by any means, electronic or mechanical, including photocopying, recording or by any information storage retrieval system, without prior written consent of the publisher. This material is based upon work supported by the National Science Foundation under Grant No. IOS-1249925. Any opinions, findings, and conclusions or recommendations expressed in this material are those of the author(s) and do not necessarily reflect the views of the National Science Foundation.

ISBN 978-0-941933-02-5

Design by Jen McCleary Art \& Design, Drexel Hill, PA

Council on Undergraduate Research

734 15th Street NW, Suite 850

Washington, DC 20005

www.cur.org

Printed in the United States of America 


\section{Table of Contents}

Introduction

Mary L. Crowe and

Bessie Guerrant

Career Mentoring: Everyone Wins

Amy L. Chang

A Society's Role in Changing

the Climate

C. Brooke Bruthers

College Is an Option for Me

Michelle Carnicle

Mentoring Is Fun

Jena Lipham

Wind-STEP Is Everything

James Cotter.

A Greater Level of Balance

Esther Goldthwaite

It Is Not About the 10-Page Lit Review Niccole Villa Cerveny...

Climate in the Classroom Nicola Plowes

Students Are an Asset Thomas B. Higgins
Mentors for Classroom Roles Michael Newsom

I Am Your Insider Chryssa Michelle Maloney 27

The Light at the End of the Tunnel Angelica Rose Galvan

A World of Gray Possibilities Kendell M. Pawelec.

Solving the Maze Joshua McCausland

Revamping a Course to

Change the Climate

Miriam Segura-Totten 35

Celebrating the Process Anastasia Lin. 37

The Language of the Universe Joseph L. Graves Jr.

39

Curiosity Opens Doors Monica Gerber

A Student Changed My

Approach

Crystal Scott...... .43

This Class Is an Oasis Louise Temple.
Students Helping Students Lauren Dorn

The Golden Ticket

Shelly Brown-Jeffy.

My STEM Family Jarvia Meggett

Chutes and Ladders Claudia Benitez-Nelson

The Value of Building Personal

Relationships

Paul L. Beasley

Freedom and Responsibility Aisha N. Conwell

Personal Responsibility James N. MacLeod

Sometimes Structures Are

Not Enough

Bessie Guerrant

It Is Not Rocket Science

Sandra Gregerman.

Further Reading

About the Authors and Editors 
Mentoring through the Transitions: Voices on the Verge 


\section{Introduction \\ Mary L. Crowe and Bessie Guerrant}

For decades, we have heard about the leaking pipeline of female students and students of color out of STEM, with a disturbing gap in involvement, persistence, and achievement in these populations. We lose students at transitional junctures such as the move from high school to college or from community college to a four-year institution - a time when the familiar climate, culture, and support systems are left behind. This publication highlights individuals, programs, and institutions succeeding in stemming the flow at these critical junctures.

Rather than present an exhaustive literature review of what works, this publication features the authentic voices of those who have participated in or built inclusive, supportive environments for all. Peer-reviewed manuscripts that cover student transitions can mask the real and emotional impacts of a program on individual lives. The diverse essays here address climate, preparedness, and/ or mentorship. These stories illuminate the often hidden dynamics, emotions, and realities of the educational and career journey.

A short reference section also is included to assist with further reading. 


\section{Career Mentoring: Everyone Wins}

\section{Amy L. Chang}

Less experienced members of a profession seek to learn from more experienced members about insights into their field and, ultimately, to feel like they are welcomed and belong to an important professional group. Members who may be new to the field of science want as much information as possible to decide whether a scientific career is for them. Members who have been in the profession for a longer period have knowledge and insight that have been learned and practiced over time.

In a 2014 study of student and early-career members of the American Society for Microbiology (ASM) about microbiology careers, nearly 1,000 respondents said that a career mentoring program was the most helpful resource that ASM could provide. Some of the biggest concerns about entering the workforce were competition for jobs (68 percent), job stability (48 percent), low salaries (34 percent), insufficient hands-on experience ( 28 percent), and "two-body challenges" (that is, involving an individual and a partner) in seeking work (23 percent). There are many challenges facing those who want to pursue science, and it will take all ASM members to lead the next generation of future microbial scientists.

Every Member a Mentor is a proposed ASM mentoring program where all members will help less experienced individuals explore different career options and make employment decisions. Mentees may seek answers to questions such as the following:

(1) Whom should I consult with?

(2) How might a mentor help me?

(3) How might my first decision about my career help shape my career prospects?

(4) What do I expect to learn?
(5) What options might I consider? (for example, talking to mentors with different specialties)

Those planning on a science career clamor for better understanding of career choices that build on their scientific training, love of the microbial world, and inquisitive minds.

Mentoring programs provide insights that have been learned and practiced over time. $\mathrm{Ca}-$ reer mentoring helps others maximize their potential to succeed as scientists and contribute to the profession. Career mentoring provides insight into the workplace, people, and climate. Career mentors help mentees (1) understand the workplaces' unspoken rules and prevailing culture; (2) identify, hone, and perfect needed skills; and (3) understand the quality of work expected and the meaning of high performance. Mentees seek opportunities to shadow career scientists who provide a peek into a new world. 
In the microbial sciences, career mentors can come from diverse positions and environments: clinical, applied, environmental, and so forth. For those in college, the primary role models are usually those conducting academic research. But employment positions and environments expand beyond the academy, and students just embarking on their educational journey have little to no access to explore these positions. Every Member a Mentor seeks to connect microbiology job providers to job seekers across all dimensions of the profession so that they can explore career opportunities and make more informed career decisions.

Career mentoring helps mentees develop a brand identity, set realistic career goals in alignment with prevailing employment trends, and tailor training and resumes to achieve those goals. Mentors can ask probing questions to discern mentees' unique abilities and translate these into a marketable skill set. Mentors can share their unique stories about entry into a career, highlighting important decisions, people, and transformative experiences. Mentees can gain knowledge and confidence about their decisions.

Mentoring requires a commitment of partners. A mentoring relationship is built on trust that is earned and founded on shared knowledge, experiences, and respect. To be successful, career mentees must be able to receive honest feedback-the kind that provides an opportunity to take a step back and re-evaluate the view of a situation or personal aims. Career mentors must be realistic about prevailing employment trends, push individuals outside of their comfort zone, and talk through the pros and cons.

Every Member a Mentor starts by tapping the entire ASM membership to participate. Even the members who are undergraduates can serve as mentors to less-experienced students. Jeff Maloy, an early-career scientist serving on the Council on Microbial Sciences, states, "Not everyone is going to feel like they have a ton to contribute to career mentorship efforts (in particular, younger members and student members may not feel qualified to participate). However, there are different kinds of mentorship including psychosocial mentorship that can be useful even when second-year undergraduate students are talking to first-year students." By tapping the entire membership-even the more inexperienced members of ASM-the program transcends the hierarchy found in science and calls upon developing a host of relationships: peer to peer, boss to subordinate, and subordinate to boss. ASM President Peggy Cotter states,

\section{"A mentoring relationship is built on trust that is earned and founded on shared knowledge, experiences, and respect."}

"The point is to recognize that everyone has something to contribute and to get started." For students, their most vital role can be as highly motivated learner-discovering new information, developing new skills, meeting new people, and building new relationships. 


\section{A Society's Role in Changing the Climate}

\section{Brooke Bruthers}

The American Physiological Society (APS), established in 1887 , has demonstrated a longterm commitment to building the next generation of physiologists conducting basic and biomedical research. APS has supported the training of underrepresented minority (URM) physiologists since 1921, when the Porter Physiology Development Fellowship was created; in the mid-196os it was nurtured by the leadership of A. Clifford Barger, Edward W. Hawthorne, and Edward P. Radford into the graduate-level program it is today. Barger would later become APS president (1970-1971). APS began a formal education program in 1987, which has since grown to provide education programs at the pre- $\mathrm{K}$, $\mathrm{K}-12$, undergraduate, graduate, postdoctoral, early career, and established investigator levels, with a particular emphasis on programs that increase the diversity of the scientific research workforce.
APS believes that enhancing the training of undergraduate students, graduate students, and postdoctoral fellows is essential to attracting and retaining a diverse group of researchers that produce high-quality, reproducible research leading to improvements in health and health care. APS has long demonstrated its commitment to supporting students and trainees at critical junctures by providing opportunities for summer research fellowships, travel and research recognition awards, professional skills development courses and workshops, mentoring, and outreach. Many of these programs are focused on supporting URM trainees, as well as broadening participation and interest in physiology research careers. APS also commits to regular program evaluation to determine program outcomes, effectiveness, and areas for improvements.
APS aims to recruit and support students; develop critical skills; increase professional visibility; provide opportunities for recognition and mentoring; and develop professional networking and APS knowledge via awards, fellowships, programs, and resources (see Table 1). At the undergraduate and graduate levels, APS programs and fellowships encourage excellence in physiology education and the development of young scientists. Programs and activities are available for students, as well as resources for undergraduate education and career exploration. These include the following:

- Student awards, fellowships, and events. APS recruits students to apply for undergraduate student research experiences and supports them with stipends, career and professional development, travel to APS meetings and conferences, as well as 
TABLE 1. Select APS Programs and Resources for Undergraduates and Their Faculty Mentors

\section{Program/activity}

Research fellowships and research

excellence awards

Faculty awards and fellowships, faculty development, and faculty learning resources

Networking resources, online resources, and other initiatives

\section{Undergraduate students and faculty mentors}

- Summer Research Fellowships (IOSP ${ }^{a}$, Hearst $^{\mathrm{a}}$, STEP-UP ${ }^{\mathrm{a}}$, STRIDE ${ }^{\mathrm{a}}$, UGREF, and UGSRF)

- Horowitz/Horwitz Research Awards (abstract-based)

- Video Contest

- A. Clifford Barger Underrepresented Minority Mentorship Award

- Bodil M. Schmidt-Nielsen Distinguished Mentor and Scientist Award

- LifeSciTRC

- Local Undergraduate Research Awards in Physiology (LURAP)

- APS Trainees Online Community

- EB Meeting

- Mentoring Forum Blog

- Minority Physiologists Online Community

- Minority Travel Fellowship Mentors ${ }^{\mathrm{a}}$

- Online Communities

- Physiology Understanding (PhUn) Week

- Professional Skills Training Instructors/Mentors

- Undergraduate Researcher Blog

- Undergraduate Researcher Social Media pages

Targeted URM program

awards for excellence in physiology research. APS is also involved in developing resources and materials for undergraduate faculty development through its own programs and in collaboration with other organizations.
- Student professional skills training and career development. APS offers professional skills training courses for undergraduate students, graduate students, and postdoctoral fellows. Students are encouraged to explore the multitude of exciting, yet challenging, science career paths.
- Professional development. APS has developed extensive resources for undergraduate education that can help students and faculty to increase their knowledge of physiology, enhance their pedagogy and course content, and advance their teaching careers. APS offers professional develop- 
ment through its meetings, online and traditional courses, and training fellowships.

- Research skills projects. In collaboration with numerous organizations, foundations, and institutions, APS develops innovative projects to support and promote excellence in science education, physiology research, and career development. These include undergraduate research projects, collaborative projects with other nonprofit scientific organizations, professional development programs, and curriculum development projects. APS sponsors the projects with additional support from federal agencies and private funders.

- Meetings. APS works to assist students throughout their career transitions. Many of the APS diversity programs have a mentoring component so that students and trainees become a part of the network of scientists. The cross-disciplinary annual meeting of APS, Experimental Biology (EB), draws more than 10,000 attendees annually. The program not only offers scientific research talks and poster sessions but also career and professional devel- opment symposia. Topics have included work/life balance, job search and negotiation strategies, mentoring, career paths/ development, networking, communication of science, and sexism in science.

- Undergraduate orientation and poster session at EB. APS hosts an orientation session and a poster session for undergraduates who have submitted a first-author abstract to physiology. Both events draw more than 100 undergraduates each year. At the orientation session, members of the Career Opportunities in Physiology and Trainee Advisory Committees provide an overview of the meeting and offer tips for first-time attendees of EB. At the poster session, more than 150 APS members speak with students about their research. Graduate departments are also invited to sponsor a recruitment table as a method of outreach to undergraduates as they consider graduate school options and other career steps.

- Mentoring. APS promotes and supports mentoring through travel fellowships, skills training courses, awards for mento- ring excellence, and a blog with extensive information on mentoring topics.

- Networking opportunities. APS offers numerous networking opportunities for students through activities at EB and interactions within its online communities.

- Outreach opportunities. APS encourages its members to participate in K-12 outreach. The APS national outreach program, Physiology Understanding (PhUn) Week, and the Life Science Teaching Resource Community (LifeSciTRC) both provide a multitude of outreach resources.

- Recognition. APS and its 12 disciplinary sections sponsor 213 abstract-based awards for students/trainees and awards for members, including awards for excellence in research, teaching, mentoring, and professional development.

Through a well-rounded approach that welcomes, supports, prepares, and recognizes students throughout their career path, APS aspires to inform students that their disciplinary scientific society can be their "professional home" for the long term. 


\section{College Is an Option for Me}

Michelle Carnicle

The University of Minnesota, Morris WindSTEP program is designed to help Native American students become prepared for and succeed in STEM fields. As a former participant, current college student, and current teaching assistant, I would say the program exceeds its goal. Wind-STEP helped me gain a variety of skills that prepared me for college. The program taught me how to live on a college campus, manage my time in an efficient manner, and learn proper classroom etiquette.

Moving away from home can be a difficult process, let alone sharing a living environment. Because of this, the program allowed us to live in the dorms on campus and learn what dorm life entailed. We were assigned a room and a roommate, and given the challenge of figuring out how to make our private space communal. This was difficult at times, as some people do not have the same daily routine or the same type of living habits; however, we still needed to figure out how to co-exist. This preview helped me to transition smoothly to college living.
I believe time management is the most important skill. Wind-STEP runs on a set schedule that promotes good health, socialization, and studies. The program did a good job exemplifying the proper balance among these three aspects. We started the day eating breakfast together-a thing many college students take for granted-then we attended class. After class, we were given free time that we were encouraged to spend with friends, working out, or asking questions. Although attendance in college is not always mandatory, Wind-STEP integrated its importance in my mind. The first step to being successful is showing up. We were not given a bedtime; however, this caused us to learn the hard way about the importance of sufficient rest.

The time-management skills learned in Wind-STEP are applicable to college life. For example, for every credit hour in college classes, you are expected to study or work on material for three hours each week. At first, this does not seem daunting, until you realize how many other things there are to do. The balance among schoolwork, good health, and a social life is harder for some to maintain than others. I witnessed friends who were unable to find this equilibrium, resulting in academic probation with the possibility of expulsion after multiple incidents. If it was not their grades that suffered, it was either their mental or physical health. The program taught me that you have to take care of yourself as well if you want to be successful.

The directors and professors of WindSTEP explained proper classroom etiquette and their expectations for students. It was important to distinguish between the expectations of high school and college. Even though the program is designed for high school students, it holds the participants to the same standard as college-level students. For example, a rule in high school is asking to go to the restroom; however, in college, it is inappropriate to disturb class. In the Wind-STEP program, students were encouraged to ask questions when they needed further explanation. Toward the end of the program, we had to prepare material for presentation to a tribal council. Because the professors and teaching 
assistants understood that some students may not have had much prior presentation experience, we practiced presenting in front of them and were given individual critiques. At first, it was uncomfortable for me; however, I feel those moments were crucial to my ability to accept constructive criticism.

Not only did I gain useful skills in WindSTEP but also met with admissions staff and learned about what the university could offer to potential students. We received a campus tour, which informed us of the amenities available. We also met with some faculty members; this was extremely beneficial, as it gave me the impression that the faculty are approachable. In fact, the professors and mentors in the program stressed that we should keep an open line of communication with professors, as they are real people and understand life situations.

Overall, participating in Wind-STEP made me feel that going to college was an actual option for me-previously, I had been hesitant about attending college. During the program, I gained more knowledge and insight then I could have ever imagined in as little as two weeks. Now I am a student at the University of Minnesota, Morris pursuing a biology degree.

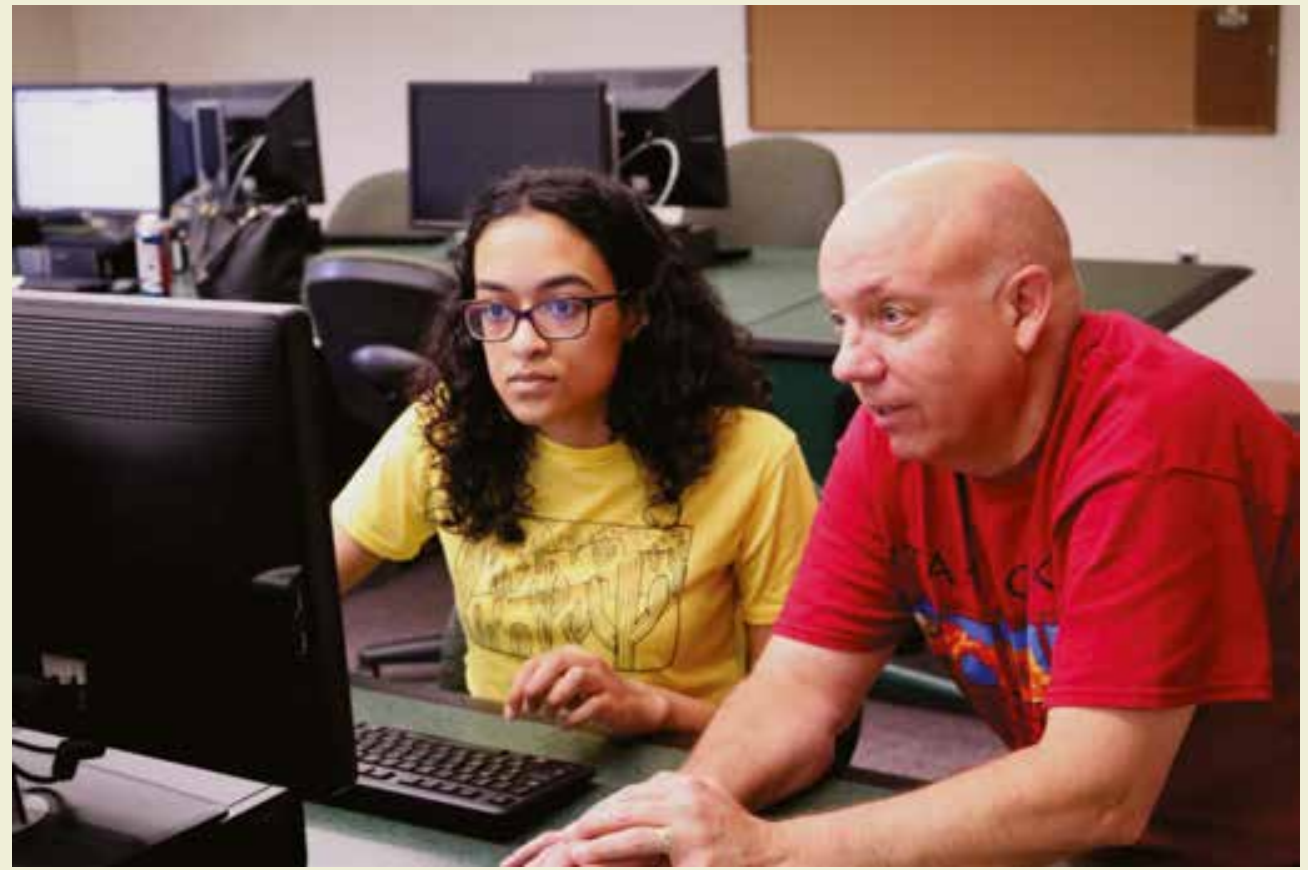

GIS instructor Douglas M. Adams, right, works with Piscataway Township (NJ) High School student Soleil Echols during the University of Minnesota, Morris Wind-STEP program, which seeks to encourage Native American students to pursue STEM careers. 


\section{Mentoring Is Fun Jena Lipham}

I have been a mentor for the Wind-STEP program for three summers and have never had such a good time with the students with whom I have worked. I heard about the program from my boyfriend who had participated in it as a student for several years before college. I had no idea what the program was, but I work with a lot of groups on campus that encourage students to attend the University of Minnesota, Morris, so I figured this would be a fun opportunity.

Being a mentor for the Wind-STEP program has been one of my favorite activities, because I don't get to work with younger kids as much now that I am on a college campus, other than first-year students, but having the connection with these high school students and helping them with their college search process or their entry into a STEM field has been really cool. On my end, it has been awesome to see them grow and bond during the summer and to follow them on Facebook to see what they are doing after the program. For them, I suppose it is like having an older sibling or a role model. I have had students tell me how much they love me and will miss me; they shed tears at the closing presentation. This just makes me realize how much mentor- ship means to these students and how much it meant to me when I was participating in similar programs and had someone there for me. There are about seven past participants with whom I am still in contact, and it's always really good to hear that they have decided on a college/university and a major or are so excited to return to Wind-STEP next summer. The afterclass activities are just as crucial as their work in the lab. I think it is really important for these students to have that separation from working in the lab, coming back to the dorms and having fun with people closer to their age. Since I have been a mentor for the past three years, I have worked with different kinds of mentors and students. Not everyone mentors the same, and not everyone likes to be mentored the same, so it is important to have a range of leaders and people from each gender because there have been cases where female students don't connect with male mentors or male students don't connect with female mentors. Representation matters, which makes for a fun group, but it is important to ensure that everyone is taken care of on another level.

I love learning about the cultural and traditional sides of the students' lives as Native
Americans, and I foster a discussion on this topic with them. It helps them feel more comfortable and open up to each other, because it's exciting to hear similarities and differences in their lives since they often come from different places and are all Native students doing something that is not typical for their people. They should be proud of that and who they are and be able to connect and bond. Native American students in general and those interested in STEM fields are vital to the Morris campus and are vital to each other. Having the support and community feeling keeps these kids in school and allows us to push them and each other.

The Wind-STEP program always receives high compliments when I share what it does with people who are not familiar with it. Through this program, students become interested in STEM fields, interested in the university, and interested in pursuing a career in the college world and beyond. I am thankful for the time I have spent with the program and the time my boyfriend spent in it as a student, because I truly believe it pushed him and other students to take up a career in a STEM field and expanded their horizons. I know it has expanded mine. 


\section{Wind-STEP Is Everything}

\section{James Cotter}

The Wind Science Talent Enhancement Program (Wind-STEP) of the University of Minnesota, Morris (UMM) is a two-week residential program for rising Native American high school juniors and seniors who are interested in STEM careers. The program goal is to provide a "college-like" experience to Native American high school students in an effort to inform, prepare, and support them as they begin their transition to the postsecondary level. A positive attitude toward education is cited as a factor in successful matriculation of minority students (Burtner, 2005), and the Wind-STEP program offers a unique opportunity for students traditionally underrepresented in the sciences.

From 2010 to 2018, Wind-STEP has focused on wind energy and its application to the needs and desires of reservation communities. Wind-STEP participants learn about alternative energy strategies, GIS systems, and environmental assessment as well as opportunities for careers in the sciences. They discuss science ethics and interact with $\mathrm{Na}-$ tive American college students majoring in STEM fields. UMM admissions advisers ac- quaint them with the process of applying to college and the availability of scholarships. Visiting Native American educators describe Native styles of learning (e.g., Cajete, 1999), and UMM education success counselors discuss accomplishing the transition to college.

In addition to academics, Wind-STEP participants learn about the area. They take a one-day field trip to Pipestone National Monument to learn about an important geologic resource and a canoe trip down the Pomme de Terre River to observe the 1890 os hydropower dam constructed for milling (followed by a Wind-STEP community picnic).

For the capstone project, Wind-STEP participants select a subject to study and complete research using GIS to identify a potential site for a wind turbine on a nearby reservation. Wind-STEP students studied the Upper Sioux Agency in 2010, Lake Traverse in 2012, Rosebud in 2013, Leech Lake in 2015, Yankton Reservation in 2016, and the White Earth Nation in 2011 and 2017. Subjects have included zoning regulations and setbacks for structures and roads, FAA regulations for airports, FCC regulations for communication infrastructure, historical severe weather and tornado risk, soil types and drainage, wetlands, and endangered species. Each student then generates a risk-assessment map for the particular study subject. At the end of the projects, all of the individual maps are "overlain," and the participants decide if circumstances will allow the placement of a turbine and, if so, where it could be located. The students then present the results of their research either to the UMM community or (as they did in 2010 and 2012) to the tribal council.

Five to ten students per summer have participated in the Wind-STEP program. There are three faculty members. Three UMM Native American undergraduates who are teaching assistants live in the dorms with students, organize social activities, and coach the students in public speaking. For many of the Wind-STEP participants, it is their first time away from home for this length of time. At times, the transition has not been easy, and some participants have left the program. But most participants have a rewarding experience. 
When asked the question "What is WindSTEP?", participants wrote: "Wind-STEP is everything"- Native American high school students studying wind turbines, wind, and other forms of alternative energy and using science to benefit communities. Students learned about college life while living in dorms. They interacted with college students and enjoyed nighttime storytelling. WindSTEP participants make friends, meet new people, and learn from role models. They "break out of their shell," experience new things, and have fun.

\section{References}

Burtner, Joan. 2005. The Use of Discriminant Analysis to Investigate the Influence of Non-Cognitive Factors on Engineering School Persistence. Journal of Engineering Education 94: 335-338.

Cajete, Gregory. 1999. Native Science: Natural Laws of Interdependence. Santa Fe: Clear Light.

\section{"Wind-STEP participants learn} about alternative energy strategies, GIS systems, and environmental assessment as well as opportunities for careers in the sciences. They discuss science ethics and interact with Native American college students majoring in STEM fields." 


\section{A Greater}

Mentors have been an invaluable part of my education. My relationship with them has been unique. I was homeschooled through high school, and my family's approach to education was mentor based. I had the experience of a Commonwealth School, which is a collection of homeschooling families coming together to hold classes and combine resources. I was fortunate to grow up with a number of exceptional people educating me, and their efforts led me to become an ambitious and devoted student. Thanks to their influence, I developed a deep love of literature and writing, as well as a desire to further my education through college.

Entering a community college was challenging for me. I went from spending the majority of my time in self-guided study to having structured classes and much more assigned homework than usual. I am an introvert, and although I was socially capable, I found the interaction with other students could be exhausting. I was accustomed to receiving feedback on my work, but I had never experienced the traditional letter-grading system. In my first semester, I worked very hard to receive all As, becoming somewhat obsessed with never allowing myself to drop below that standard.

I started attending college full time during my second semester. For the first time, I was branching outside of my personal areas of interest in English and the humanities, and taking a science course. My perfectionism was at an all-time high, and I was moving even further away from my comfort zone. I had signed up for a physical geography course taught by a faculty member who had been highly recommended to me by advisers and other students.

This course was the closest thing I had found in college to my personal background of mentorship. The instructor did not see my classmates and me as a conglomeration of students but rather as individuals deserving of personalized attention. One of the strongest impressions she made on me was her understanding of my introverted nature. She always respected my desire to observe rather than vocally participate in her discussion-based lectures, and she was always ready to listen when I did have something to say, whether in class or after class was over.

Even though I was outside of my area of interest, I enjoyed her classes and their content. Her influence in my life became especially strong when I took my first exam. It was one of my earliest experiences taking tests, and I was terrified that this exam would prevent me from earning an A in the course. Before the exam, my classmates and I completed an analysis that asked how we expected to perform on the exam and factors in our lives that might affect our performance. I remember writing of my nervousness. I said that I really just wanted an A-my perfectionism exposed in my use of the word just.

When I received my exam grade, I was horrified-I had received an eighty-five. It was the first time I had received a B on anything. During the next class period, I shared in a post-exam analysis how I felt my inexperience in the sciences and my anxiety over the exam had limited my ability to perform. I felt unsure of myself and ready to give up. After I submitted that analysis, the faculty member reached out to me. She said that there was still plenty of time to earn an A in the course. She knew I was new to science and my focus was elsewhere, but she said she was proud of me for doing well in the class. Those words meant everything to me. 
As I have continued in my college career, I have still, at times, struggled with perfectionism. But my mentor's response to my fears has helped me to realize a greater level of balance. She did not tell me that my fears were ridiculous and that I shouldn't stress so much about little stuff. She did not tell me that I should stop worrying about grades. Instead, she focused on the positive aspects and helped me appreciate my accomplishments. I don't think she realized how much her words helped me as I moved forward in college, but they have continued to have an impact on me. I have since had many meaningful interactions with my mentor. I have learned from her amazing teaching philosophies and expertise, and benefited from her understanding.

This experience with mentorship taught me valuable lessons. Mentors are people who are there when you need extra help and support. They are people who share words of comfort and belief when you are struggling to feel that you can accomplish the tasks before you. Mentorship is not some grand concept or idea. We have the most impact when we are simply there for the people who need us.
"The instructor did not see my

classmates

and me as a

conglomeration

of students

but rather as

individuals

deserving of

personalized

attention." 


\section{It Is Not About the 10-Page Lit Review}

\section{Niccole Villa Cerveny}

I am a community college professor who values research experience for undergraduate students as early as possible. Not only does problem-based, active learning substantially benefit STEM students at any level, it also has great capacity to inspire seasoned professors. Thus I am always surprised when my colleagues insist that students in their first and second years of college are underprepared to conduct authentic research projects and limit the experience for these students to uninspiring 10-page literature reviews-where most of the work is done independently outside of class and with little guidance. This opinion is widespread throughout undergraduate institutions. It seems that preparedness with regard to conducting research is characterized by a familiarity with the literature, understanding of the discipline, an ability to self-direct when unsupervised, and potential to contribute to ongoing studies by the instructor or department.
My first year at college was challenging. I am a first-generation Hispanic female who attended university on scholarship. My family was proud but not much of a resource for surviving at university. Although I had finished near the top of my class in high school, I was terribly unprepared for large classes, limited contact time with the professors at an R1 institution, and the responsibilities firmly placed on my shoulders for just about everything unfamiliar. At the time I was a business major, and my adviser tried to talk me out of this particular course because it was known to be difficult. I was very fortunate to take a geoscience laboratory course during my second year with a professor who did not share the assumption about the capabilities of early undergraduate researchers. When I became brave enough to voice my interest and excitement about the geosciences to the professor, my undergraduate experience took a turn for the better. The professor took the time to find some specific areas of interest in the subject and gave me journal articles to read. He indicated that there would be discipline-related jargon, but he would answer any questions I might have. Although I was not a major, he engaged me in a research project that taught me about scanning electron microscopes, sample preparation, mineralogy, rock decay, and geomorphic processes. I would scour the stacks of the science library and try to find related books and articles that the professor had not read, and learned to read relevant research papers. Over the remainder of my undergraduate education, I completed several research projects with this professor and took all of my elective courses in this field. I learned that packrat middens cut on a wet-saw are terribly smelly-defining a career with rocks rather than organics, how lichen growth can be used for climate research, and how the material found in rock fractures comes primarily from aeolian fallout rather than the decaying rock. 
The last project resulted in a publication with my name (listed first) and my work in an actual book! Although I finished my accountancy major (because I needed a job-and what would I do with rocks?), the publication process meant that I stayed in contact with the geoscience professor. Although accountancy pays well, it was not exciting to me, so I enrolled in graduate school five years later to pursue geoscience.

I was not prepared to conduct research as an undergraduate, but that connection with someone who supported me, nudged me, told me that my ideas were good, and showed me how to find the tools and information to enhance my ideas was the key to my staying in college, achieving higher gains in learning across all of my classes, providing confidence, and feeding my potential.

Today I hold a $\mathrm{PhD}$ in geography with an emphasis in geomorphology. I teach first- and second-year, introductory level, geoscience classes. My students may have been at the top of their high school classes or somewhere else along the curve. The transition from high school to college includes a shift of responsibility for achieving success to the student, yet many have no idea how to handle this responsibility. Some who do understand are not always sure how to direct their efforts. Today's students have so many more choices for careers and opportunities that it can be overwhelming. I think that students need more guidance within all aspects of their college experience. Consequently, every student in my
"...I am always

surprised when

my colleagues

insist that

students in

their first and

second years

of college are

underprepared to

conduct authentic

research

projects..." classes conducts research. Due to the teaching load of community college professors, the experience does not exactly resemble my experience; however, it is hands-on and student directed.

Most of the time, these students undertake a class-wide project related to subjects covered in the course in which the nonmajor students utilize their best contributions within their available time. For example, someone who is interested in marketing will take on the role of publicizing the project, utilizing their knowledge of the science from class and their budding public marketing skills possibly acquired from another class. It is my job to facilitate the scientific techniques for students at varying levels, including exposure to the relevant literature. This approach has generated many exciting topics, as my introductory-level students are not indoctrinated into the discipline and can generate some wild ideas that are sometimes very fruitful. When they are not so fruitful, we still advance our ability to conduct scientific research learning, and reach an understanding of the benefits and limitations of such an approach. Because projects are student generated, they often establish self-directed components as they need and want more time on the projects. Frequently, projects even benefit the department or the institution. Often first- and second-year students contribute publications to advance the discipline. Thus the positive outcomes of the projects are multiple and reap many rewards for instructor, student, and institution. 


\title{
Climate in the Classroom
}

\author{
Nicola Plowes
}

As we move between different life stages, the one constant is change. The goal in introductory biology for nonmajors at my institution is to facilitate the transition between high school expectations and college expectations and to prepare students for upper-division courses and the working world. Although the core of each course is a set of content-specific objectives, the soft skills and habits of mind fostered are arguably of higher value to the students than discrete facts about science, especially if adapting to new climates is a goal.

I am a first-generation American and the first in my family to navigate the U.S. higher education system. As such, I have learned that faculty members need to practice what they preach. To help students adjust to the new expectations of a college climate, faculty members need to be good examples. They need to be on time, kind, approachable, responsive, and transparent. Being punctual demonstrates respect for other people and their time. Being kind and approachable, even if experiencing frustrations outside of class, demonstrates emotional control and professionalism. Being responsive and transparent means respecting students' time-sensitive queries, as well as being clear and open about expectations and ways of teaching and assessing. As teachers, we are the role models for the students' new climate.

There is a vast quantity of practical life skills that can improve students' academic outcomes, quality of life, and success in the workplace. High school expectations and differences in cultural norms can result in a kind of culture shock for students entering the new climate of college. In high school, many students were kept on time and on track by parents and teachers-now they are held responsible for being seated and ready. They need to plan out each week-balancing social life, financial obligations (work), and academic demands. When and how much should they study? How can they negotiate the inevitable hurdles-a stomach bug, a change to a job schedule, and so forth.

My approach is to set clear expectations for due dates and have the information accessible on the learning management system as well as posted during lecture. For assignments that are more than a couple of days in the future, I provide reminders. The students are not ready to listen to a single announcement and follow through. A few weeks into each semester, I show them how I organize my time-using apps for making lists, calendars with tasks/ events, and reminders that arrive on a phone, as well as recording tasks in old-fashioned ruled notebooks. A week before each exam, I ask students to write out the dates and times when they plan to study their notes.

Arriving for class on time is an important skill that is easily overlooked. Positive reinforcement is provided by taking attendance (worth points) at every lecture meeting. Late students lose points. Students who email before class to provide notification that they will be late or absent gain points. Such procedures build skills of good communication. It takes practice to know that advance planning is required to arrive at a particular location at a particular time. As some cultures have more flexible interpretations of "on time," enforcing attendance policies (with less than five minutes of flexibility) helps students to achieve workplace expectations.

Other noncontent skills important in the modern workplace include proficiency in basic word-processing programs such as formatting that produces functional documents. 
Fundamental ability in the use of spreadsheets to store numbers and make simple bar charts would be a baseline expectation in many businesses and professions. Using email appropriately, uploading documents, sending documents, creating legible scans, and using digital media also are customary expectations in the workplace. Keeping an organized notebook or file folder is another skill developed. Some students catch on easily, whereas others need to be guided and reminded, not only to maintain their organized notes but also to understand why organization is important.

Students also need assistance in learning practices at college that can help them in planning their future, such as discovering programs and support systems at their institution, seeing faculty during office hours and asking for career advice, developing professional relationships with faculty, gathering information about grants and scholarships, and applying for internships to obtain experience and connect with potential employers. They need to understand the benefits of maintaining a solid grade-point average and applying themselves so that they may complete their education, obtain a desired position, and repay their student loans. We can equip all our students to succeed in the many climates that they will encounter in college, in the workplace, and in life.

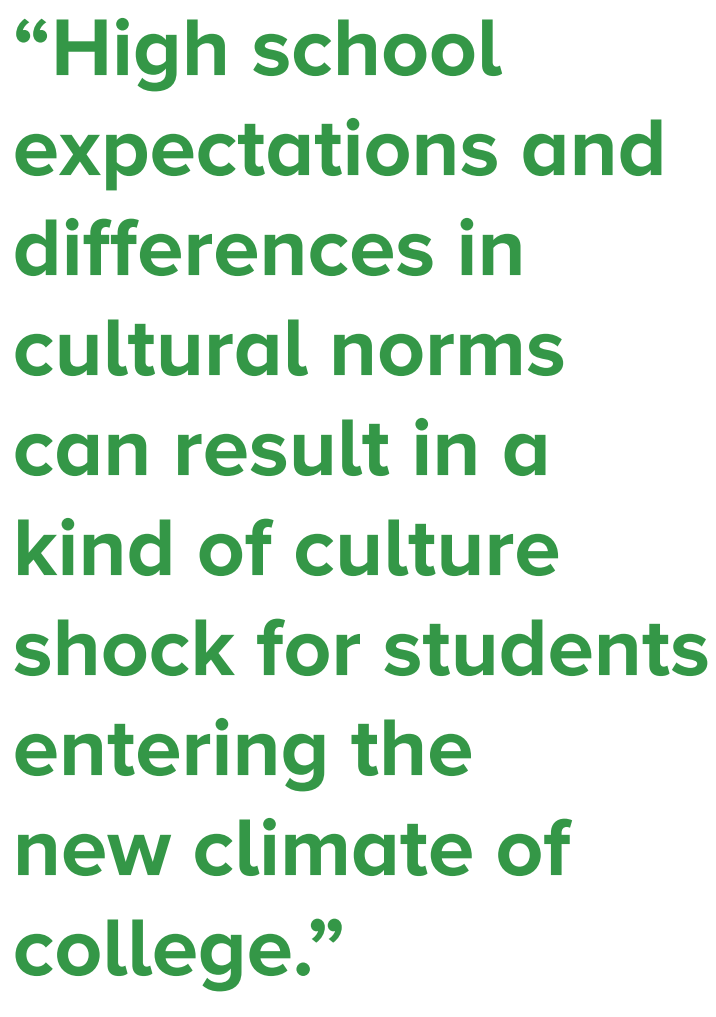




\title{
Students Are an Asset
}

\author{
Thomas B. Higgins
}

Not long ago, I had the opportunity to spend two years at the National Science Foundation (NSF) as a program officer in the Division of Undergraduate Education. This new role gave me the chance to see higher education and the daily life of a faculty member from a new perspective. I temporarily left my home institution and my department but kept my ties to colleagues and friends, I gained some distance from the classroom and the day-today interactions with students without separating myself from the profession of teaching, I acquired a wider view of the state of higher education, and I more deeply appreciated the ongoing efforts to reform and improve student learning in other STEM disciplines. Now that I have returned to faculty life, I can fully appreciate how this change has allowed me to see my role as a professor in a new perspective.

One thing that shocked and saddened me was the increasingly prominent role of the student-deficit perspective in institutional culture and the dialogue of higher education. It seems that, when something goes wrong inside or outside the classroom, the default position is to assume it is the students' fault due to their intrinsic lack of knowledge, motivation, or planning. I first noticed this implicit bias in my own language. Once I began to listen for it more intently, I realized I was not the only perpetrator-it was everyone. I would hear it in conversations with colleagues, consultations with prospective investigators, and presentations at conferences. If this is what we are saying to our colleagues, we are, without a doubt, communicating it to our students as well. If our students don't believe we believe in them, why should we expect them to learn from us?

The student-deficit model has been studied extensively, but my operational use of this construct is that it is the belief that students come to us broken, and it is our job to fix them. There are several things wrong with this perspective, but the worst thing is that it makes the classroom a dreary place to teach and to learn. Why would we force this dystopia on our students and on ourselves?

Instead of treating of students as projects that need our attention, it is better (and more productive) to embrace students for what they really are: individuals with assets and agency. By understanding our students' motivations and focusing on the positive attributes they bring to our classrooms, we can infuse a sense of challenge and fulfillment into our teaching practice. Yes, students come with misunderstandings and misconceptions about our favorite subject, but if we embrace their mistakes and misconceptions, these become teachable moments not only for students but also for us as faculty members to learn about and improve our own teaching practice.

I fully believe that no effort to reform and improve student learning can succeed in an environment where students are subject to the implicit bias of the deficit perspective and thus that they are not being treated fairly. Although I know I cannot change the environment and culture of my institution by myself or overnight, I do know that I have control over the environment and culture of my classroom. If I do not consciously try to improve it, I would be remiss. To force myself out of a knee-jerk, student-deficit perspective, I have sought to consciously practice the following three principles: 


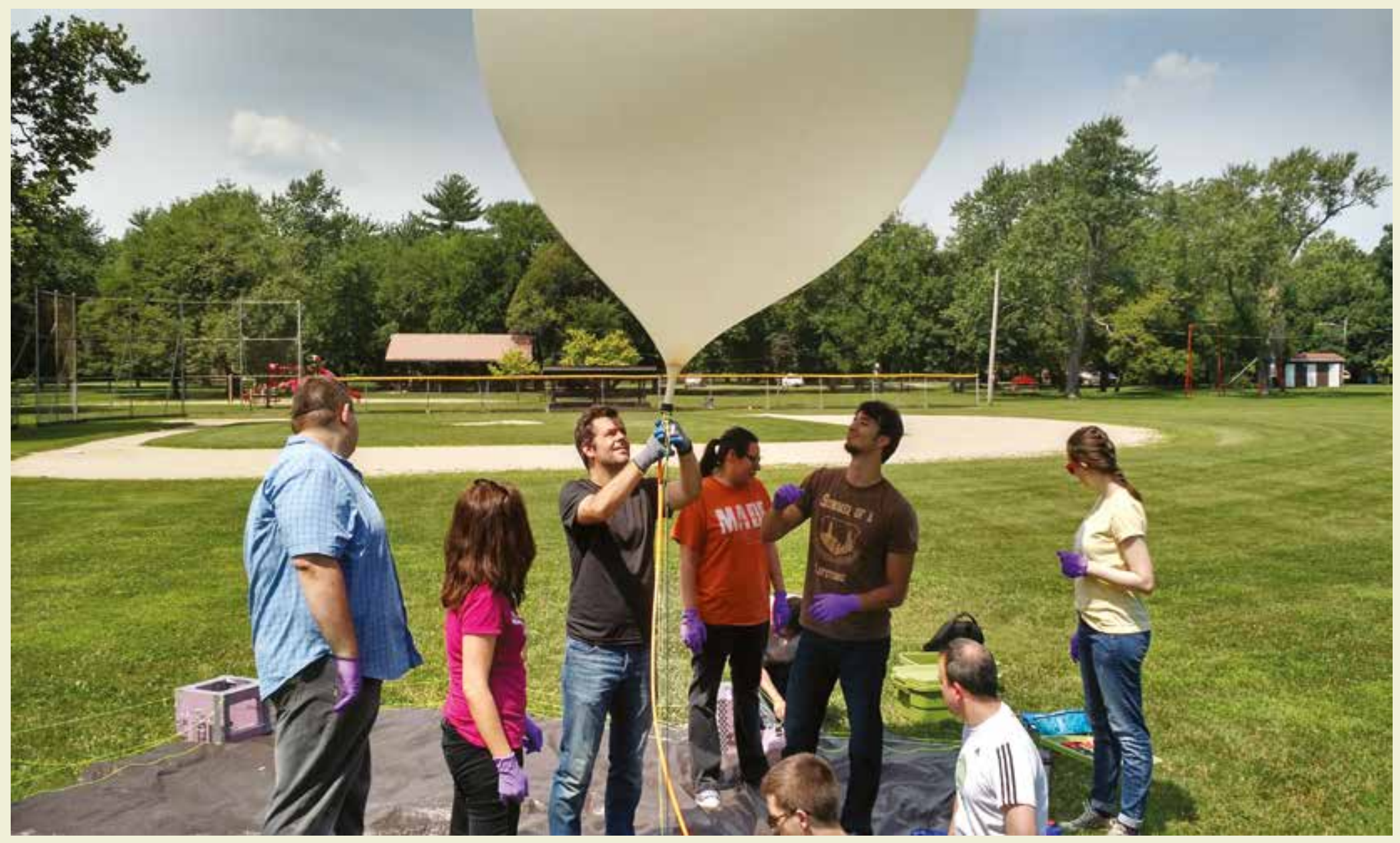

Professors Andrew Kerr (third from left) and Phillip Vargas (second from right) receive instructions from an experienced cohort of City Colleges of Chicago research students in how to fill a high-altitude latex weather balloon with helium. The purple box in the back left holds the scientific payload of experiments designed and built by the students. The balloon ascended to approximately 100,000 feet before popping and parachuting back to earth. The payload and experiments were recovered later that day. Photo courtesy of Michael Davis. 
(1) Never speak ill of a student, in any case. Words have power and influence other, more subtle aspects of how we communicate our true thoughts and intentions. Since I am the leader of my classroom, my words and thoughts have an outsized impact on everyone else who is part of it.

(2) When a student does something unexpected, don't react. Instead, pause, reflect, and ask a question. When a student makes a mistake, there is a reason. Look for the reason. This should not be interpreted as giving the student a break if he or she doesn't deserve it, but at least find out the underlying causes or motivations for an action instead of jumping to a conclusion. If I do this, students will at least view me as fair.
(3) Finally, model the desired behavior for students to practice. Life is not fair: it is capricious and chaotic, especially for young adults. If I practice what I preach and take ownership of the mistakes I make, students will at least feel like I am on their side, even when life is not.

Have I been perfect with my practice? Definitely not. But I think I have been successful. After I returned from NSF, I taught two sections of first-semester general chemistry with laboratory. Of my 56 students, only two dropped the course. This 3.6-percent drop rate is much lower than my pre-NSF 28-percent drop rate. This may be more anecdote than evidence, but the lesson I learned is that my unconscious habits and attitudes have an important impact on my classroom environment and my students' willingness to be a part of it.

\section{"Model the desired behavior for students to practice."}




\section{Mentors for Classroom Roles}

Michael Newsom

Working as an adjunct faculty member has opened my eyes to the challenges faced by schools and teachers. I've had the opportunity to work for several schools in Chicago that cater to students with wildly different economic backgrounds, but two factors are constant. First, all schools have limited resources and rely on part-time faculty to teach as much as 50 percent of the course load. Second, many adjuncts are knowledgeable in their fields, but they have limited understanding of educational theory and pedagogy.

After roughly five years of working as an adjunct instructor, I had the opportunity to take a seminar on educational theory. Up until that point, I had been teaching by instinct with very inconsistent results. The seminar pointed me in a better direction by explaining how the classroom really worked and cleared up a lot of problems that had stumped me by changing my ideas about the person in the center of the classroom. The instructor for the seminar became a model for what I hoped to achieve in my own classroom.

I began teaching with good intentions but with no idea how to make them real. My strategy was to simply copy my favorite teachers from the past. Mylesson plan was to lecture all the time. My expectations were to dazzle every student with a careful selection of well-ordered topics. The students would work hard during class and still be motivated to study on their own. Things, of course, did not turn out that way, but semester after semester, I would tinker with small pieces of my course to try and live up to those original intentions.

Teaching was not as effortless as those teachers from the past made it seem. Most students were not doing well in my class no matter what I did. For the first few years, my attitude was essentially "teach harder," and I spent my time writing better lectures and more clever homework questions. I was trying to refine what I did and expecting the students to respond. The classroom is not a laboratory, and a similar set of circumstances is not guaranteed to lead to the same results. The inconsistency was very frustrating, and the success of a class felt like it depended exclusively on factors outside my control.

My breakthrough came during the Learning and Teaching seminar at the City Colleges of Chicago. This was a 10-week series of weekly meetings addressing topics about educa- tional theory, active learning, and classroom management. The class was small-only about 10 people from disciplines ranging from math and language to art history. The participants worked together during class to address these topics and reflected on their learning in a series of individual essays. Most classes were run as a group discussion with very little emphasis on lecture. The reading was significant, but the class assignments were constructed so they did not depend on the reading too heavily. The short duration required the class to move at lightning speed, but further research was suggested for anyone who wanted more detail on a given topic.

The course provided the circumstances I needed to better understand my role in the classroom. It was great to share experiences with people I would not have met under ordinary circumstances despite how much we had in common. It was reassuring to know other people had faced the same difficulties and to hear how they overcame them. I remember being particularly impressed by a colleague who changed his entire syllabus in the middle of the semester based on issues discussed in the seminar. 


"The most
important lesson I
learned...was the
importance of the
social aspects of
learning."

It was also interesting to watch how the instructor handled the class-doing small things like arranging tables to foster discussion and bigger things like changing the schedule to accommodate last-minute cancellations. It was an approach to the classroom that I did not know was possible. During the class, I would often ask myself, "Is this really the assignment?", because it was so different from the work I had given my class. At first, it was difficult, but over time, I came to appreciate the learner-centered approach.

The most important lesson I learned during the seminar was the importance of the social aspects of learning. Students learn more if they work together, and it is far more important for them to work out meaning amongst themselves than to absorb information uncritically from the instructor. Put simply, classrooms are more effective when the teacher stops trying to be the "sage on the stage" and learns to become the "guide on the side." This attitude places the student at the center of the learning process and results in a more significant learning experience.

I have been slowly transitioning my class away from a traditional lecture-based course to one with more active learning assignments and more group assignments that require conversation with other students. This has been challenging, but the results have been significant. Students participate more and learn more when they are given the chance to do something rather than to sit still and listen. I am currently researching strategies to change my approach to laboratory work.

Everyone remembers the great teachers of their childhood. However, once you start teaching, you realize it requires a strategy. A small amount of guidance goes a long way in this regard. The small changes I have made since reevaluating my role in the classroom have led to better results from the students and less inconsistent experiments for me. 


\section{Am Your Insider}

\section{Chryssa Michelle Maloney}

I am a tutor at a community college in Chicago, and the students with whom I work come to trust me for my knowledge, my ready ear for their concerns, and my approach in taking each and every one of them seriously. I give them my time, and I give them my best, to prepare them for life beyond college. Through the years, I have noticed that each student offers a unique perspective into how I might become a better mentor and guide. I learned that, as their tutor, I am their insider to the complexities of college life.

As a tutor, I am the students' insider, but I am also the insider for you, the faculty member. I know facets of your students' lives and your pedagogy that students may not wish to admit in front of peers or even to you. They ask me embarrassing questions, confide in me, and seek me in their most confident and desperate moments. From these experiences, there are three simple things I have consistently noticed in the students who need my support.

(1) A need for empowerment. Azariah came to me for tutoring after a series of missed lectures and assignments. By the first of the given problem set, I watched as Aza- riah became entrenched in a self-made logical quagmire. When faced with this situation, many students have learned to lean into their own anxiety; in this proactive way, they take control of their education. But Azariah didn't respond as such, and it would take many hours of relationship-building to learn why the commitment to school was nill.

One day, after I asked, "How are you today?", Azariah shared with me that a parent had been in surgery again.

"I'm so sorry. That is tough."

"Yeah.” Azariah sighed. "He's going to have his other toes removed now because of the diabetes, and all his doctor appointments are during class."

"That's terrible. So, you go with him and miss class?"

"Kind of. He only wants me to drive him there. Medicaid provides a driver, but he doesn't trust a stranger."

My heart sank. "Familismo?” I asked.

Azariah's eyes lit up. "Yes! How did you know?" In some families, the family comes first regardless of what individual sacrifices need to be made. It would take many fol- low-ups and mock conversations amid actual tutoring before Azariah felt comfortable negotiating boundaries (with an otherwise very supportive family) to ensure class would no longer be missed.

What can a person do with helplessness once it is fully believed? If student voices are quelled, it becomes more difficult for them to be engaged in their learning. If student voices, no matter how hidden, are quelled by us, then who else can they turn to?

(2) The belief that struggle is unsightly. Alex was engaged, thoughtful, and polite. With meticulous handwriting, deliberate and courteous question-asking, and great eye-contact that implied intent listening, Alex consistently finished the assigned math homework. Surprisingly, however, the completion of said homework always took place during our sessions, and despite much effort to study at home, Alex was not doing so well in trigonometry. When a mediocre exam grade left Alex inconsolable, I immediately moved us to a quiet location to talk and related that I was sorry to see that the exam grade had such a devastating effect. I learned that 
Alex was the first person in the family to attend college and could not ask for help from family members. A younger sister was looking up to Alex, and Alex did not want to let her down. Alex stated, "The other kids just seem to get it instantly, and it takes me all night."

I opened up briefly about my own academic struggles and reminded Alex that the person able to teach mathematics today was formed, not born. I reminded Alex that on another floor of the building was a team of quite understanding and well-trained professional listeners who would love to give an hour of time to talk when stressors such as this one popped up. I walked Alex to the counseling center and departed with the reassuring message "I will see you next week. We will get through this." We did.

It is my belief that the most prepared students have been exposed to the multifaceted nature of success via an insider to the process. Having had several insiders myself-personable mentors willing to embrace their unique cognitive hiccups-I began to communicate openly to Alex about my own past struggles with certain concepts. This gave Alex the chance to shed a positive light on small blunders but not become entangled in them. I also showed Alex that seeking professional help is one way that successful people solve problems.
(3) A frustrated dependence on the instructor. "So, what you're saying is that the photons travel in sort of a membrane. Like a herd." Casey blew me away with an incoherent explanation of wave-particle duality.

Aware of it or not, Casey was overwhelmed. The expectation in college is, of course, that students enter it after embracing the belief that obtaining knowledge is worth a struggle.

"The teacher teaches off of pre-made PowerPoints and doesn't grade our homework," said Casey. "They [sic] just put a checkmark on it and don't answer their emails. The test prep is just a packet of problems with an answer bank, and we're not sure when it'll be."

How do we convince students that even the most mind-bending concept is worthy of our time and mental effort? Not only that, how do we convince them that they must actively seek this challenge? Surely it starts with good communication and clear expectations.

As it turned out, Casey didn't realize that reading the textbook was less a suggestion and more a law of effective learning but also didn't realize that a lack of feedback and wordy text read from lecture slides resulted in pretty lackluster communication. As a first-semester college student, Casey simply didn't know that self-directed learning was such an integral part of the course and so struggled until the expectation was set. This student needed more courteous communication, and clearer goals and expectations from the instructor. From me, building skills that could foster independence would prove valuable. From Casey, patience and persistence were required. The self-reliance that Casey gained through independent learning, as well as the organizational skills co-implemented by us, appeased much of the anxiety that stemmed from lessthan-stellar lecturing.

A solution: Teach students to feel empowered, confident, and proactive. Preparing our students to participate in their communities and welcome budding challenges on the horizon will require they think well, question themselves, and create meaningful ideas. These are skills conferred by a good education. Within our system that provides such an education, I believe that my role as a tutor is to put myself out of a job by teaching students to feel empowered, confident, and proactive. For this, I need your help. If we prepare our students in such a way that eventually leaves me unemployed, it would be because we successfully communicated that they are all empowered beings able to co-pilot their own growth. I would be satisfied with that. Until that day of unemployment, I will always be searching for ways to better embrace my role.

What is your role as our students travel their educational path? May the perspectives of your assistants, tutors, and students provide insight for developing into the teacher you wish to become. 


\section{The Light at the End of the Tunnel Angelica Rose Galvan}

First-year undergrads can often feel like they're in a long, dark tunnel by themselves. They're on a path, but they can't see anything, and they're unsure of where they're going. Mentors are the people who believe in students and encourage them to continue pursuing their dreams. They are the light at the end of the tunnel.

When I first met my mentor, she was soft-spoken, was very polite, and had a slight British accent. I can distinctly remember panicking because I did not know how to pronounce her last name, and I was relieved when she told me to just call her by her first name. In the lab, she assigned me to work on wire coatings and scaffold assembly. It was simple, but still, she often appeared at my shoulder to ensure that I did everything correctly. My mentor was very quiet, serious, and focused in the lab, so I tried to be the same. For the first month, I dipped wires in poly(vinyl alcohol) (PVA) solution and assembled scaffolds. It was not exactly the exciting research experience that I en- visioned, but I liked being in the lab because it reminded me of my engineering shop back home.

The college transition for me was pretty rough. For the first two weeks of college, I locked myself in my dorm at the end of the day and cried. Yes, I'm an emotional engineer. When I'm happy, I'm an alkali metal, and when I'm sad, I'm a halogen. I didn't think that homesickness would be a problem because I'm an introvert; I'm good at being alone. However, I realized that it is difficult to be the best version of yourself when you are not surrounded by the people who believe in you. The lab was the place that allowed me to focus all of my energy and not be overwhelmed by homesickness or everything else at the University of Michigan. In the lab, it was just me, the copper wires, the PVA solution, and the scaffolds. I was a noble gas, and the lab was my comfort bubble.

However, for someone who is naturally an alkali metal, it was inevitable that something would eventually cause me to react. For me, it was soap. It happened when I was researching liquid-liquid extractions for my chemistry lab homework. I read something about how surfactants decreased the surface tension of water and got a brilliant idea. I thought that if I added soap to the PVA solution, it might help the solution wet on the copper wires better to create a more homogeneous coating. I had to test it, but I couldn't run out to the lab at 3 am. Instead, I performed the experiment with sugar water, soap, and a fork in my dorm room. It worked, and my mentor heard all about it on Monday morning.

I know it is a rather simple thing to let undergraduates add soap to solutions, but when my mentor allowed me to try out my crazy idea, it meant a lot to me. That was the first time I realized my mentor was willing to genuinely listen to my ideas and opinions about the project. Although I knew nothing about scaffold design and nerve repair, my mentor never judged me for my lack of knowledge; she was 


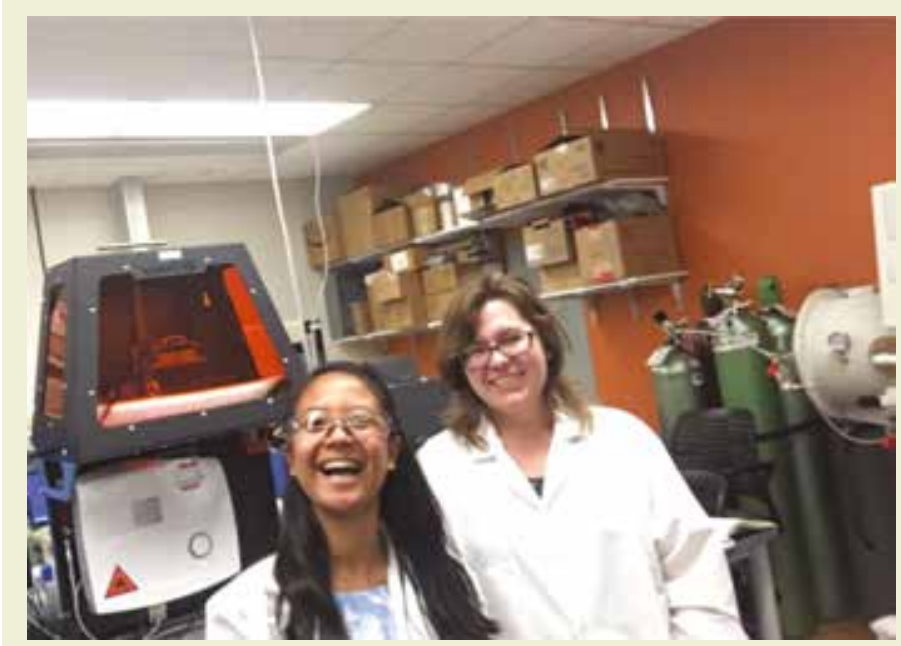

Student Angelica Rose Galvan, left, with her mentor Kendell M. Pawelec in the lab at the University of Michigan.

patient and approachable. She treated me as an equal, listening to my idea and supporting my enthusiasm for experimentation. That's why I always felt comfortable asking her questions.

After that, my mentor slowly reduced the frequency of telling me what to do and allowed me to try mini-experiments in the lab. Knowing that she trusted me enough to figure out things on my own gave me the confidence to own my project and believe that I had what it took to pursue a career in research. In high school, I had a mentor who introduced me to the joy and excitement of the design process.
She helped me realize that I had a passion for research; she's the reason why I'm studying engineering. However, my undergraduate mentor is the person who helped me realize that I had the potential to be a good scientist, and she became a role model to me-an example of the person I wanted to become. She inspires me to continue pursuing my dream of earning a $\mathrm{PhD}$ in the future.

In the small moments between experiments, during our walks between the G. G. Brown Building and the Energy Institute or during our chats in her office, my mentor would ask me about my classes, and I could tell that she was genuinely interested to know how I was doing. I would ask her questions about her experiences studying abroad, doing research as a graduate student, or just conducting research in general, and she was always very open to sharing her experiences with me. As I got to know my mentor and she got to know me, I became more comfortable being myselfin the lab. I was nolonger able to contain myself as a noble gas; I became an alkali metal. For a first-year student who had not yet figured out where she belonged at a huge place like the University of Michigan, it was nice to know that there was someone who understood and cared and that there was a place where I could be myself. That's why my mentor is the person who makes me feel at home at Michigan.

I believe that the turning point-the moment when we both made an effort to transform our relationship-was when I stayed in Ann Arbor to do research over the summer. Inside the lab, I've learned a lot from planning and performing my chemical synthesis with my mentor and looked forward to our tea-break chats. Outside of the lab, we've enjoyed playing tennis, watching Shakespeare in the Arb, feeding the squirrels on the diag, and eating ice cream together. She is one of the few people on campus who know me completely, inside and outside of the lab. We have a great mentor-mentee relationship because we both found the courage to open up and make the effort to get to know each other simply as people. Kendell Pawelec is more than a mentor to me; she is also my friend.

Passion for a research project and a good relationship with a mentor is not something that happens by chance; it is a gradual process that requires patience and effort. So, I encourage future undergraduate students to approach their research experience with a curious mind and an open heart. Take the risk to experiment and explore. Find the courage to ask questions and initiate conversations with your mentor, because mentorship is a twoway street. If you take a chance to open up and show people who you are, it might encourage them to open up to you as well. 


\section{A World of Gray Possibilities}

Kendell M. Pawelec

At some point in a research career, the opportunity will arise to become a mentor to an undergraduate student. This can be the result of hours spent sifting through resumes and interviews or stem from a brief introductory e-mail. Regardless, the decision of whom to mentor is only the initial hurdle in making new students into productive members of the lab. On the surface, the job of the mentor is to teach lab safety and research techniques to mentees and set them on a course to be productive as soon as possible. However, the most important step of the process, and what sets the tone for the rest of the relationship, is how these students are welcomed into the lab and integrated into a culture that is very foreign from the rest of their undergraduate learning experiences. As part of my own academic journey, I have made numerous excursions between labs and across disciplines. In all of these travels, at every stage of trainingundergraduate, graduate, and postdoctoral-two aspects in particular always set the tone for all further interactions: interfacing with the human environment and defining expectations. Thus, I feel that there should be a greater awareness of how mentors approach the introduction of undergraduate students to research.

Undergraduate students have had extensive training to prepare them for the rigors of assimilating packets of new knowledge and demonstrating their mastery in prepared exams. However, the research environment does not follow a prescribed set of rules, and most labs exhibit a type of organized chaos. As a completely different environment from everything previously experienced, the lab can pose many uncertainties for new recruits. There are the obvious difficulties such as learning bench techniques or organizing and analyzing data, but more fundamentally, students may struggle with questions about how they should identify and achieve a "right" answer. They wonder where they fit into the lab organization and how to measure their success in research.

The transition from black-and-white absolutes to a world of gray possibilities is tricky and fraught with struggles. For many undergraduate students, every lab course and experiment has been strictly defined throughout their education, and students are judged on one correct answer. As anyone who has been exposed to research knows, there are no guarantees that a hypothesis will be proven and certainly no guarantee that a given approach will yield results on the first try. After all, if research was easy, it would not be any fun! Layered on top of this is an often nebulous organization of fellow researchers, with no clearly defined expectations of what will be accomplished. For mentors, these are critical issues that undoubtedly need to be addressed

Setting the stage for research is ensuring that students have all the support that they may need, something that starts at the initial welcome. All mentors are aware that research is becoming increasingly interdisciplinary; a lab requires the convergence of many opinions and expertise, and is therefore a nexus of people with very different skill-sets: undergraduates, graduate students, technicians, postdoctoral scholars, and instructors. Although an overall theme of the research may (or may not) be well defined, every individual has a unique scope of work, specialized knowledge, and relatively flexible working hours. However, the ups and downs of research are what all have in common. When interactions between researchers in the lab are personal and everyone knows the name of their peers, the lab becomes more than an area for gen- 
erating data but also changes into a support network. Thus, the mentor can give no better welcome than to integrate a mentee swiftly into this supportive environment.

What can undergraduate students gain from this support network that they cannot gain solely from their mentor? In the course of their studies, undergraduates are often constrained by their coursework and only interact with a subset of people within their major. The diverse group composing a lab can provide interactions that offer insight into other possible careers or spark an interest in a previously unknown field. On a more mundane front, there will always be times when mentors are unavailable to students. Mentees need to be able to rely on others around them to help answer their questions. Also, appearances really matter in the beginning stages of the mentor-mentee relationship. Undergraduates, just finding their feet, are often loathe to appear "stupid" and admit that, after two days, they have not memorized where all the supplies are stored in the lab. Instead of asking, they may pull out every drawer, open every cupboard, and generally make a 20 -minute experiment into a 2 -hour ordeal. This is where the support network can come in handy. Asking questions of strangers is difficult. Asking questions of peers is easier and goes a long way toward making a lab a nonjudgmental space and, by extension, one that is more safe and enjoyable for everyone.

The success of a project and a researcher is another aspect that can be determined during the first week of mentorship. Setting up a successful experience can be as simple as outlining expectations at the start-not just the expectations of the mentors but also of the mentees. Expectations can direct the working relationship (how many hours per week, the level of independence, and so forth) or outline the outcomes desired by undergraduate researchers from their research experience. Some students want room to play and make hypotheses. Some are far more comfortable being directed throughout their time at the bench. To make the most of everyone's time, it is important to be attentive to the wishes of each student and to learn the definition of success for each student.

Adapting to undergraduate expectations does not imply that mentors cannot have their own expectations of students. As the one directing the undergraduate's learning, the mentor has an obligation to consider what a lab experience should teach. Before new undergraduates arrive at the lab, some skill or concept that the mentor wants to impart to undergraduates should be identified. For example, although students may want minute direction on how to perform experiments, they should also be expected to understand the logic behind the experimental hypothesis. If students are performing a repetitive task such as analyzing data or running the $x^{n}$ variations of a matrix, then they should have a firm grasp of the background literature and its role in the overall project. In such a scenario, students not only learn but also become more invested in the research and excited about their contribution.

No matter how much time and enthusiasm brought by a student or mentor to a project, some individuals are never truly comfortable in research or in the particular research of the experience. Undergraduate research can still be a success, as long as the expectations of mentors and mentees have been fulfilled, and they have had fun. In the best mentor relationships, it is not just students who learn and grow but also mentors. For those like myself who started their journey in academia as undergraduate researchers, becoming a mentor is a wonderful way to gain perspective and realize how far you have come. It is an opportunity to capitalize on the best mentor experiences, sharing a love of the field, explaining its inspirations, and-best of all-meeting new people. It all starts with a very warm welcome-and who knows where it goes from there? 


\section{Solving the Maze Joshua McCausland}

As a homeschooled student, I used to worry about the toughness of college life-I did not have much experience with science or competitive writing beyond what I could read and study at home. During my initial transition to the University of North Georgia (UNG), the realms of research and academia surprised me with their ability to be enlightening and fun, and inspired me to pursue them as career paths. Navigating the complex landscape for admittance to graduate school and advancement toward my dream of a science career proved challenging. Fortunately, I had incredibly supportive faculty mentors at UNG who helped catalyze my future and jumpstart my critical transition to graduate school by assisting me in my application to a post-baccalaureate research fellowship at the National Institutes of Health (NIH) through the Undergraduate Scholarship Program (UGSP), a highly competitive scholarship that provides college graduates with the opportunity to do basic research as a postbaccalaureate scholar.

I currently attend Johns Hopkins University (JHU) as a $\mathrm{PhD}$ student in biophysics. Graduate school has been one of the most rewarding experiences of my life so far, but the climate here is completely different from that of UNG. From what my UNG mentors described to me, I expected that grad school would have much higher expectations of me on a daily basis, but I was unsure what that really meant. Interestingly, my most important training at UNG was not just pipetting or chemical-mixing; it was the ability to read and analyze a paper. UNG developed my critical faculties and helped me to think about the meaning of my data and the big picture of a project.

Transitioning to JHU was a big leap, and I do not think I could have come here without the support of my NIH fellowship position in honing the skills I acquired at UNG, for graduate school has high expectations. NIH trained me in a diverse array of areas, from daily lab work to competitive writing for graduate school applications. This is why I feel grateful for my amazing mentors at UNG. One helped me learn how to write competitive applications for scholarships, pushing me to work nonstop on application after application until we reached success. Another mentor pushed me not to learn more lab skills but to step back and think about the scientific literature. I had learned how to read papers by that point, but she encouraged me to hone my ability to read, analyze, and present papers in my advanced cell class. Both of these professors helped cement my success.

Once I started at NIH, I began to realize that primary research was a different world. My first few weeks were spent panicked and stressed trying to adjust to the environment and figure things out. However, once I found my stride, I realized I was much better prepared than I thought, and my lab colleagues commented that I had more than just great bench skills. I was assigned a journal club presentation three months after starting. The journal club meets regularly to present and talk about recent scientific papers. Fortunately, one of my UNG mentors had structured her advanced cell class just like a professional journal club. My lab colleagues told me that my journal club discussion was the best they had experienced, "raising the bar" for the rest of the postbacs coming to their lab. Ever since then, I have been involved in reading and discussing literature with my mentors at NIH, and they helped further develop my skills. I frequently found that UNG had trained me to succeed. 


\section{"...I am developing new skills that I never anticipated, such as learning how to network with other scientists in my field and take the initiative to become a leader in campus groups."}

There were definitely aspects of graduate school I did not expect when I was an undergraduate-namely the focus on grant-writing. My PhD mentor expects me to write grant applications until I earn one, which is great practice for me since I want to run my own research lab someday. However, at UNG I did not initially have much experience applying for competitive scholarships or grants. This is where one mentor's encouragement came in. She pushed me to apply for scholarship after scholarship until I earned the NIH UGSP. After she helped me apply for the NIH fellow- ship, I used her training to apply for, and nab, a travel grant for an undergraduate conference later that year through the biology major honors society. To date, I have applied for the National Science Foundation's Graduate Research Fellowship Program, and I am putting together an NIH grant to help fund my research. I have learned how to approach competitive writing partly because of my foundational work at UNG.

I would not have made it this far without the support of my mentors. Because of their unending patience, I crafted a personal state- ment, both out of experience and competitive writing, to obtain a place at my top-choice graduate school at JHU. The university attracted me for multiple reasons. Since I want to run my own research lab, attending a premier research institution provides several opportunities to practice writing grants, try the latest scientific techniques, and push for high-impact research. Most important, I am developing new skills that I never anticipated, such as learning how to network with other scientists in my field and take the initiative to become a leader in campus groups. Science relies on teamwork and clear, successful communication of ideas. However, I doubt I would have been as well prepared for graduate school if it were not for the people who were there for me at UNG and NIH. I am continually grateful for the help they gave me, and I still feel amazed that I attend a university like JHU. Now, I plan to pay this service forward. I have already started mentoring bright, young undergraduates and rotation students in my lab. I hope I can instill the same academic curiosity and passion for science in them like what my UNG role models did in me. 


\section{Revamping a Course to Change the Climate}

\section{Miriam Segura-Totten}

Since I became a faculty member, I have mentored many students through transitions from undergraduate to graduate studies. My mentoring relationship with students often begins when they enroll in one of my courses at the University of North Georgia (UNG), such as the upper-level Advanced Cell Biology elective. I designed this course in response to changes in content of the Medical College Admission Test (MCAT). There were a number of topics in the new MCAT that the university's required courses did not emphasize. In looking through these topics, I realized that focusing on the comparison between normal and cancer cells would target a number of them such as the regulation of metabolism, stem cells, and immunology. This approach also capitalized on my expertise in cell biology. In addition, since this elective would attract premed students, the focus on disease was a natural choice.
The MCAT also had been modified to place a stronger emphasis on critical thinking, so I thought carefully about how I could integrate this learning outcome into the course. To develop students' critical thinking skills, I used a constructivist pedagogical approach, which would engage students in activities compelling them to create their own knowledge and increase critical thinking, problem solving, and understanding of the scientific process. I relied on primary and secondary sources instead of a textbook, since reading and analyzing research articles also increases critical thinking. Since I wanted this class to increase student interest in scientific research, I focused on journal club-style article discussions instead of lectures. Thus the course was transformed into a hybrid of undergraduate class and graduate seminar; students were expected to contribute to the conversation so that the discussion of topics would be full and rewarding.
One mentee who was part of the first course cohort in 2015 exhibited a strong interest in scientific research. Right from the start, this mentee took advantage of every opportunity I offered from solving problems based on real research to designing follow-up experiments for articles discussed. During the semester, I witnessed this student's growth in thinking like a scientist: working out complicated research problems became easier for him, and he began asking insightful questions and critically evaluating data in a way reminiscent of research scientists.

Even though the majority of students who enroll in this course have their sights set on medical school, many stated that taking this class resulted in a deeper appreciation for biomedical research. Additionally, many students who took the course said that they were better able to analyze complex texts and that the course helped boost their performance on the Critical Analysis and Reasoning Skills 


\section{"...the course}

was transformed

into a hybrid of

undergraduate

class and

graduate

\section{seminar."}

section of the MCAT. Being able to critically analyze the primary literature is also an important skill for undergraduates interested in graduate studies. Based on this experience, I would advocate for departments to consider developing courses like this one to (1) raise student awareness of and interest in research, and (2) nurture skills necessary for success in scientific research in those students interested in graduate studies. Optimally, a student's course of study would include several classes that use primary and secondary sources so that the student could obtain a glimpse of how research is conducted at the highest levels. This is especially important in primarily undergraduate institutions like UNG, where stu- dents do not have access to the same level of research experiences available at research-intensive institutions $(\mathrm{R} 1)$.

The mentee from the 2015 iteration of Advanced Cell Biology eventually received and accepted an invitation to attend the Biochemistry, Cell and Molecular Biology PhD program at the Johns Hopkins University School of Medicine. Although this student is an exceptional individual who has an innate passion and aptitude for scientific research, his experiences at UNG-including involvement in research, participating in a class modeled after graduate seminars, and access to an institutional support structure-allowed him to maximize his chance for success. 


\section{Celebrating the Process}

\section{Anastasia Lin}

After stepping into the newly created role of assistant dean of student research and scholarship at the recently consolidated University of North Georgia, I was tasked with directing the undergraduate research office as well as establishing an office dedicated to assisting students in finding and applying for nationally competitive scholarships, fellowships, and the National Science Foundation-funded Research Experiences for Undergraduates (REUs). In the first three weeks of my new position, I began working with several students who would go on to become the university's first national scholarship winners. Working with these students was foundational in helping me understand my role in the application process and beyond.

One challenge faced by new scholarship advisers is learning to ask leading questions. Often, this boils down to simply asking "Why?" a lot and encouraging students to clarify points they might regard as self-explanatory. I often tell students that "every scholarship has a poster child; my job is to help you become that poster child." I assist students in thinking through their individual stories, talents, and strengths to create a coherent narrative that helps them demonstrate their suitability for the scholarship. I get to know students through multiple drafting sessions. I advise students of very different backgrounds; many are nontraditional, some come from military families, others have economically challenged backgrounds, whereas still others negotiate living as a person of color in a largely Euro-American environment. This can lead to difficult discussions; students are reticent to disclose socioeconomic status, challenges in their pasts, or other personal attributes like race or gender that may sometimes lead to discrimination. However, the shadow narrative of these traits creeps alongside the original draft. I encourage students to see speaking their truth as not what many have termed a "sob story"; instead, discussing these traits and attributes in nuanced ways allows the reader to understand students' growth and trajectory. Writing their truths also helps them better understand their own positionality, reframe their past experiences, and better understand how to successfully navigate new challenges in the future.

The students' persistence and dedication taught me the value in encouraging students to apply for more than one scholarship, what we call "appeasing the scholarship gods." In many cases, a student selects a scholarship that is not the best fit for that particular individual. Ensuring students continually apply for scholarships requires a foundation of trust and a supportive atmosphere. The stress and extra work on top of already busy course schedules can cause burnout. In addition, national applications require students to recalibrate their standards from the institutional to the national level. Applying and reapplying for scholarships takes great grit. As mentors, we can help students through the mental and emotional exercise of accepting failure and moving forward. Best practices call for us to be perennially supportive; we must encourage students to go beyond what they think possible.

One of the most important lessons I learned through working with students is that mentorship does not end after an application is submitted. Many months after applying, one student received an email informing him he was a semi-finalist for the Undergraduate Scholarship Program at the National Institutes of Health. We began discussing next 


\section{"As mentors, we can help students through the mental and emotional exercise of accepting failure and moving forward."}

steps, including the required phone interview. As a new adviser, I felt out of my depth. I knew what an academic interview entailed, but this was my first undergraduate scholarship interview. I was fortunate to draw on the expertise of members of the National Association of Fellowship Advisors for guidance on the likely components of this interview. In this process, I created a lasting professional relationship with another adviser working on the West Coast. The support and guidance of the NAFA group has been instrumental as I build my fellowship advising capacity.

To prepare the student, the interview process was mimicked as much as possible. A 15-minute period was devoted to round-robin questions asked "in character" by several faculty members. Afterward, we paused to debrief and provide feedback. Following this interview, I held a brief phone interview to familiarize the student with that mode of interviewing. Preparing this student for the interview reminded me that the scholarship process must be tailored to each applicant; some applicants need and want many interviews, whereas others become more nervous with too much prep work.

I continue to struggle with the sense of responsibility for students and their applications. I become as invested in their applications as they do; as a former Fulbright recipient myself, I know the life-changing benefits that can come from a fellowship, and I want that same experience for the university's hardworking students. Inviting other faculty and advisers into the scholarship process allows for new perspectives and ideas that ensure student success and growth.

A best practice of the office includes celebrating the accomplishment of applying or interviewing, regardless of the outcome. In this particular student's case, this meant be- ing available on the day of his interview call as well as fielding texts and emails from him as he waited nervously. Following the call, we celebrated with cupcakes. We celebrated a second time when he learned that he had won the scholarship. These small celebrations confirm to students the gravity of their undertaking and mark their hard work. As mentors and advisers, we are uniquely privy to the amount of pressure experienced by students to craft an application and write essays in new and unfamiliar rhetorical modes. The office now holds a small party once a semester to celebrate "hitting submit." The event encourages students to keep applying and allows excellent students to network and create communities that support them as they continue to find and apply for other national opportunities. Most important, it encourages students to see applying for scholarships as a process with deep and far-ranging value. 


\title{
The Language of the Universe
}

\author{
Joseph L. Graves Jr.
}

Obnoxious behavior and overconfidence provided key insights to me in graduate school.

During one class for which I served as a teaching assistant, I was rolling my eyes at every point made by the professor in his lecture. He then said, "Mr. Graves, if you think you know this material better than I do, why don't you just come down here and take over the lecture?" I did so (the topic was the mathematics of insect population cycles), and he was so impressed with my performance that he actually asked to serve on my doctoral committee. After several such episodes, the eagerness of my committee members to get me in a closed room and show me exactly how much I did not know about evolution cannot be underestimated. They succeeded.

The oral exam required to present my doctoral dissertation took place in fall 1987. Although my performance on the exam was exemplary, the committee identified a serious problem in my training: a lack of prepara- tion in formal statistical methods. Although my undergraduate mathematics background was strong for a biologist (calculus, differential equations, and linear algebra), I had never taken a basic statistics course. The committee insisted that, before I could present my dissertation, I had to take a course in statistics. I grumbled as I left the room, but the committee's decision was exactly what I needed to make the transition from graduate student to fully independent professional scientist. This is because, as Albert Einstein once said, "mathematics is the language of the universe." A deficiency in any part of the language is not something a scientist can afford.

Over the years I have observed how this weakness in biologists' training has compromised the ability to understand experimental results. Statistics allows for the analysis and interpretation of data with a view toward objective evaluation. They allow us to challenge one of our most basic form of logical bias- seeing the result we wish to see-as opposed to what the data is really telling us. In addition, understanding statistical methods helps in understanding how experiments should be designed for best results. Thus, I insist that my undergraduate and graduate students enroll at some point in their training in a statistics course. For biology students, it is best to take a biostatistics course before graduate school.

Another of the most neglected skills in student preparation is writing. On the first day of my postdoctoral appointment with Michael Rose, he stated, "you are a very good scientist, but you don't write very well." I was taken aback, because I always thought that my writing was adequate. However, in the course of a few hours, Rose demonstrated to me the deficiencies of my writing skills. In the two years of my postdoctoral appointment my writing greatly improved, and Rose and I coauthored papers. My formula was very simple (brainstorm, outline, rough draft, review, edit, and write again). 


\section{"The enemy of academic success is the lack of crucial skills..."}

The text I utilize when I teach scientific writing is Randy Moore's Writing to Learn Biology (1992). The title emphasizes the fact that one of the best ways to learn a discipline is to write about it. Professional-quality writing requires the development of a clear thesis supported with sound arguments. Arguments are reasons that the reader should believe the writer's claims, which are supported by strong information and a literature review. Performing a literature review also helps clarify and deepen ideas because the researcher learns more about both the historical basis and the current state of the discipline. In performing that search, peer-reviewed primary and secondary sources that support the argument must be evaluated. Finally, writing assists in learning spelling and the rules of grammar, such as writing clear and concise sentences, and avoiding run-on formulations.

Sun Tzu (544-496 BCE) states in The Art of War that "if you know the enemy and yourself, you need not fear the results of a hundred battles. If you know yourself but not your enemy for every victory gained there will be a defeat. If you know neither the enemy [n] or yourself, you will succumb in every battle." Sun Tzu is speaking of preparation, and his words are as valid now as they were in his time. The enemy of academic success is the lack of crucial skills; for science students, these often are mathematical and writing proficiencies. Being aware of gaps in skills and having the determination to remedy those deficiencies will guarantee success in any career path. 


\section{Curiosity Opens Doors}

\section{Monica Gerber}

"My name is Monica Gerber. I am a third-year biotechnology major with minors in premedicine, medical Spanish, and honors interdisciplinary studies at James Madison University." This is how I introduce myself, but as I read over it, I am utterly astounded by what it says. How did I get here? What decisions put me on this path? Who and what has affected my journey?

When I began thinking about college in the middle of my high school career, I thought I would major in music performance, drawing on my experience with the flute. I was under this impression for two years until I had a revelation. Music would never fulfill my curiosity and yearning to help people, but science sure would. So I decided to attend James Madison University, a powerhouse for flute players that also had a newly developed biotechnology program and ample opportunities for undergraduate research. I didn't know what that was at the time, but it sounded like a good thing to have. So I declared biotechnology as my major, having no idea what I wanted to do with it.

Fast forward to August 2015. It was time for first-year students to enroll in classes. I fol- lowed the major guidelines to a $\mathrm{T}$ and signed up for all the recommended science and general education classes. I added marching band to my schedule and started looking for one additional class. I received an email from a professor, Louise Temple, regarding a firstyear research course titled Viral Discovery. Curious, I looked into it and signed up so that I could obtain credit for my honors minor. I walked into class with no idea of what to expect. Temple stood at the front of the room and reviewed the protocols for the day. On the first day, we were enriching our dirt sample in LB broth and learning all about the lifecycle of a virus. I learned the first of many new ideas and techniques on this day, not realizing how much this experience would prepare me and open many doors for me.

Over the course of my first semester, I learned so much. I am now able to say that I can make a successful bacterial overlay in order to test for phage specificity. I am able to properly use a pipette and record data properly. I even ran my first gel electrophoresis within the first month of class. All of these things I would not have learned until the second semester of Cell and Molecular Biology if I had not taken the Viral Discovery course. I even learned the importance of aseptic technique the hard way. If I reused a nonsterile pipette tip or contaminated the sample in some other way, I would obtain skewed results. I can't count the number of times my dilutions and sample became contaminated with an unknown bacteria or different bacteriophage. But that is how the real world works; often you have to perform the experiment many times and mess up before you are able to do it properly and understand what you are doing. I also learned that even if you do everything right, there is no guarantee that you will obtain any usable results. Many students, me included, would follow the DNA extraction protocol exactly, and we still wouldn't get any usable results. That's just how the science world works. This intrigued more than anything else. If something didn't go the way I planned, why didn't it? How could I solve that problem? What could I do to improve?

Above all, what I learned from the first semester of Viral Discovery that prepared me the most for my science career was the reasoning behind the class. The viruses that we were targeting attacked bacteria called $\mathrm{B} a$ - 


\section{"...l knew that \\ I wanted to \\ learn more and \\ research more in general."}

cillus thuringiensis, a nonpathogenic strain of bacteria that is in the same family as Bacillus anthracis, the bacteria that causes anthrax. The theory is that the bacteriophages we were isolating and discovering have the potential to affect similar bacteria. Therefore, in the future, as bacteria become more resistant to antibiotics, we have the option of viral therapy. Viral or phage therapy is a type of treatment that uses a "cocktail" of bacteriophages to kill infections of bacteria that have developed resistance to last-resort antibiotics. Based on the host range of my phage, MRDukes, it could be used to treat any number of resistant bacterial infections. This medical application was just the beginning for me. Right then, I knew that I wanted to learn more and research more in general.

Around this time, one of my dear friends passed away from pediatric cancer, and I was inspired by her life to do something about this horrible disease. After I related this to Temple, she immediately knew the perfect research lab for me. She sent an email to Tim Bloss that explained my interest and recommended me for his lab. As Bloss was on sabbatical at the time, it's hard to know whether I could have joined his lab without my mentor's recommendation.

Thinking back on my experience within the Viral Discovery program as a student and as a teaching assistant, I know that I wouldn't be completing undergraduate research and preparing to apply for medical school without it. I learned countless lab techniques, and my curiosity thrived. I have my future planned out, and I know for a fact that if it weren't for the SEA-PHAGES program, the Viral Discovery program, and my mentor, I would not be prepared for the future I have within the science and medical fields. 


\section{A Student Changed My Approach Crystal Scott}

Standardized testing in public K-12 settings has contributed toward a culture of "teaching to the test" in the classroom. This is because teachers are penalized if their classes do not achieve certain benchmarks. To prevent this, the most-common approach has been to teach facts that can be memorized and regurgitated on an assessment at some point during the academic year.

In addition, students are bombarded with digital and social media nearly constantly. This has led to new, casual language with shortcuts in both format and spelling. Adding this to the fact that most formal assessments are scored electronically by a scan-tron reader, students often graduate from high school with very little exposure to critical reading of work that they have written.

When these factors are combined, a rigorous college schedule can be overwhelming almost immediately. It is not uncommon for first-year students to feel like giving up on their coursework within the first 4 weeks of a 15 -week semester. In my experience, a Phage Hunter course-I will refer to it as Viral Discovery - has helped to ameliorate the deficits in all the major areas lacking in the academic training for these students.

During my first semester at James Madison University, I taught several sections of Cell and Molecular Biology Laboratory. One firstyear student stood out fairly early. This student was taking Cell and Molecular Biology and the associated lab a full year before most of her peers. Her grasp of scientific thought, how to carry out an experiment, how to analyze the results, and how to share her findings through oral and written communications were outstanding. I decided to talk to her about her performance and ask if she would be my teaching assistant in a future semester. She agreed. When I asked her about her experience, she told me that the Viral Discovery course had made her a confident scientist and that she had isolated her own bacteriophage. I was only briefly acquainted with the program, so I decided to learn more. A year later, I was honored to be asked to participate as a faculty mentor in the program.

While part of the Viral Discovery course, I was taught how to carry out the annotation of a phage genome. We were split into teams. Although the training was exhausting, the mood was electric, and we all knew that we were in it together. We also knew we would be meeting again, in 5 months, with our star student who exemplified a job well done for the course. Many of us took that spirit into our future work, and I relayed the honor and excitement to my new class.

I was blessed with a wonderful class of bright, inquisitive, and competitive students. There were three sections, and I taught one. One student from each section would be chosen to represent the particular section. The students hoped to stand out in a group of truly 
outstanding individuals. It was a great pleasure to see the effort and enthusiasm put into the work that semester-a spirit that I saw carried into each semester I taught the course. It was even present in the one-week high school course that I helped to teach. There is nothing like the motivation of students who believe in themselves after they realize they can be trusted to carry out research to find a novel bacteriophage. There is nothing like the joy in action and deed when a student first sees plaques present on a lawn of bacteria meant to host these viruses. This excitement remains as students isolate, purify, and extract DNA from their viruses with a hope that "theirs" will be chosen as one to be sequenced for annotation. It truly is a joy to be a part of that process for students who generally have little to no practical lab experience. The process-discovery, led by the scientific method-changes their lives. They stand out in their courses. Other science professors often have mentioned that the students who have been trained to think, and carry out lab work in the Viral Discovery course, stand out.

Those who teach a course like Viral Discovery tend to be less rigid in personality, as the process of "phage hunting" can be unpredictable. An instructor must think fast, troubleshoot, and maintain a classroom of students who are at different places in their discovery for two or more semesters. What also seems to be a hallmark of those faculty members interested in such an endeavor is a general interest in their students as people. Mentorship is a role with much responsibility and one that students respect greatly. It is through an intense process, alongside a mentor who trusts them, that students develop confidence, critical thinking, and the skills necessary to appropriately communicate their experiences in oral and written forms. The students are just as proud of the work they complete as their instructor is, as it tends to be a body of work carried out as a partnership. Friendships are the typical result of the course. It is not uncommon for students in the course to seek a research home in the lab of their Viral Discovery mentor or to seek academic, professional, and personal advice from their Viral Discovery mentor. These types of relationships are not only rare to the college student but also provide a foundation of professionalism from which these students can draw, as they have truly experienced mentorship.

In one example, one outstanding student was casually talking with another. The students were joking about weekend antics and the possibility of making an irresponsible but deliberate choice. When they realized their mentor (my colleague) had heard the discussion, they joked with her about it as well. My colleague kindly told them that it was never a bad idea to make good decisions, and the scientific work proceeded. Later that weekend, one of the students in the discussion emailed my colleague. Regretful about the discussion and the possibility of making a bad decision, and unwilling to disappoint her mentor, she decided to change her plans. It was important to her to reach out, relate her plan change, and thank my colleague for being her mentor. That is the beauty and value of true mentorship.

Viral Discovery confers an advantage to students. That is clear in analysis of the data and in conversation with both students and mentors who have committed to the program. I am forever blessed to have been part of the James Madison University program supported by the Howard Hughes Medical Institute, and I have used that model in my teaching at the College of Idaho and Boise State University. I have seen students from first-generation and low-income backgrounds who likely would have "fallen through the cracks" in another environment flourish and go on to graduate school, summer internships, and professional careers with the help of this course. 


\section{This Class Is an Oasis}

\section{Louise Temple}

Curiosity brings students to the Viral Discovery course, after they have heard about it from friends or faculty members. Questions such as "Do I really bring dirt to class?" and "Is this going to be like kindergarten?" come to mind. On day 1 , students experience the usual get-acquainted activities: safety lectures and the obligatory, boring syllabus monologue. But the similarity with other classes stops there. Most of their time is spent figuring out equipment, following a simple protocol, getting dirt all over the bench top as well as into a glass flask, mixing bacteria with the dirt to make a mush, and putting the flask into a strange piece of equipment-in short, a lot of unfamiliar steps to follow. "You can't go wrong in this class," they are told, but they have trouble believing it. The instructor talks about viruses, shows a few photos to illustrate how cute they are, and talks about their medical potential as antibiotics. Most students respond, "I don't really have a clue what we just did." The instructor says that this work is an authentic research experience but that they will make mistakes. They are told that every mistake is an opportunity and that they will perform procedures over and over again to master the skills needed for the research. The students are reassured that they will understand what they are doing and why in a short time, but for now, they need to trust that the processes will yield a virus for each one of them. The instructor says that the students in the class are part of a larger community all involved in the same goals.

Fast forward a few weeks. Each student has brought in multiple dirt samples, but not everyone sees viruses in their first samples. What do they do? Bring more dirt from a different location. Despite periods of frustration, students look forward to class and are excited to look at their results. Did they see plaques this time? Was there contamination? Did results indicate a high number of phages? Did good DNA result from the purification process? In spite of the ups and downs of the results, students begin to feel more confident in their newly acquired molecular biology skills. They may even be helping their peers in other lab classes, trying not to act too cocky. But the research itself seems like two steps forward and one backward. Will they actually reach the goal of having a purified phage, DNA, and an image of the virus? Will it be a cool enough image for Facebook? Can they really name a phage after their grandmother, after their dog, or through inventing a new word?

By this time, students have become accustomed to asking questions and obtaining opinions from the instructor and teaching assistants. After all, the instructor and the teaching assistants have been through this process and know what it feels like to be uncertain, to forge ahead regardless, and to try out new ideas. Students start to believe they can trust their observations and design a valid follow-up experiment. Although mistakes and unexplained results can be frustrating, students say that they are having fun. For the final creative expression assignment, the class shares poems, songs, self-made videos, children's books, phage or infection models, cupcakes with serially diluted colored frosting, and much more, illustrating the contrasting responses to the semester's work.

For this semester, the students lived in a learning space with a unique climate. Student comments range from "this class is an oasis in my desert" and "it is such a relief to come to this class" to "this is the only class where I'm not completely anxious" and "it's like being 
in the eye of the hurricane: calm and peaceful while everything is stormy around you." Friendships from the Viral Discovery classes often endure for years because both students and instructor bonded over something great, something meaningful. The instructor might not remember the name of every student in the class later on but tends to remember the phage's name of a particular student, a result that is endearing to the students.

The scenario described here, based on student stories and quotes, reveals much about the learning environment in Viral Discovery as well as similar research-intensive classes. The climate is welcoming, challenging, frustrating, rewarding, but stressfree in the traditional sense of a college course. This is why it works for learning, for achieving success in other classes, for building personal confidence, and for understanding and experiencing the scientific process. Students

often arrive at college from pressure-cooker high schools, finding themselves in competitive programs with high-stress environments that are counterproductive in terms of effective, lasting, and enjoyable learning. The Viral Discovery course provides students with

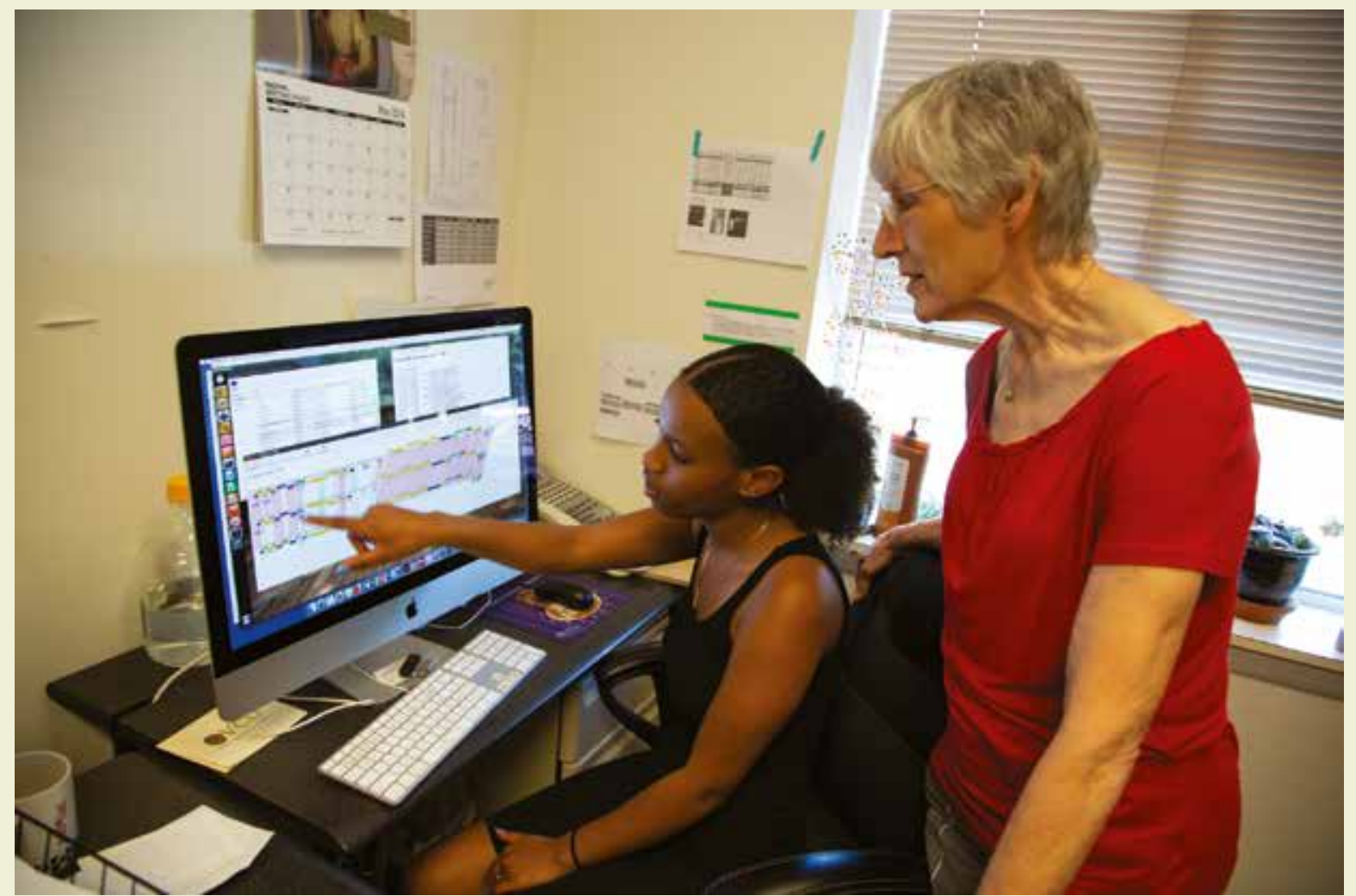

James Madison University professor Louise Temple, right, with mentee Letu Kassa. a safe place to learn and grow intellectually, a place in which they can address the real and often daunting challenges of scientific discovery. The experience gives them a toolkit that can be applied to challenging and complex situations that arise through their college years and into their careers. 


\section{Students Helping Students}

\section{Lauren Dorn}

The concept of climate brings quite a few images to mind such as the lectures in my introductory biology class about the spaces in which plants, animals, and human beings found a home. I was interested to discover that not only are organisms affected by the environment but also have the ability to affect the environment that they choose to inhabit. I could easily connect this biological principle with the realities of navigating a college campus. Underrepresented STEM students may face challenges in adapting to the new sociocultural climate that they face as they transition to college life.

As a young child, I remember talking to my friends and teachers about the many careers that I wanted to pursue. As expected, my ambitions were constantly changing. However, one common theme was sustained: my interest in life and social sciences. I dreamed of being a cultural anthropologist, studying tribal customs, studying learning disabilities as an educational psychologist, or working with infants in the hospital intensive-care units as a neonatologist. Adults in my life encouraged me to pursue my passions and to study hard to reach my goals. None of my desires were ever called into doubt or question. As I transitioned into college, I found that the same encouragement that I received in my early education was maintained by my university professors, advisers, and fellow classmates. In sharing my goal to pursue a career as a physician-scientist, I have been met with nothing but positivity. Additionally, I have benefited from academic and career advising services, research opportunities, and professional development programs. To succeed in the STEM professions, it is crucial to have support from faculty and staff members. I have found faculty members who are willing to encourage all students, regardless of their background, which provides a sense of comfort that increases my accessibility to academic resources. As a student, I benefited from mentorships as I transitioned to university. One such initiative that has been helpful to me is the Maximizing Access to Research Careers Undergraduate Student Training in Academic Research program (MARC U-STAR) at my institution. From the MARC program, I have had opportunities that have fostered my educational growth and preparation for my future research career. Amid a climate that offered few opportunities to minorities and women in the past, this program has been instrumental in allowing me to identify mentors who are willing to guide me on the path to success.

Clearly, the contributions made by the university leadership to encourage underrepresented students within STEM fields are important to producing successful professionals. I also believe that the students themselves have the power and responsibility to promote a welcoming atmosphere. Inspired by diversity and unity, my classmates and I support each other by working together. I look fondly on my experiences as a first-year college student in which my classmates and I worked collaboratively to study for exams, pursue educational experiences, and seek counsel on how to best prepare for our careers. Coming together to reach the common goal of academic and career success was profoundly encouraging and emboldening. Time spent studying in diverse groups allowed me to benefit from learning about the diversity of my classmates' experiences. From the beginning, our desire to master the material necessary to accomplish our professional goals bonded us and promoted strong relationships. Our differences unite us 


\section{"I have found faculty members who are willing to encourage all students, regardless of their background, which provides a sense of comfort that increases my accessibility to academic resources."}

to create a community and a safe space for us each to grow in our knowledge and awareness of national and global issues.

As an African American female, I have been encouraged by the increase in diversity over time among my professors and my classmates. I am proud of the fact that my university prioritizes not only having a diverse student body but also a host of faculty and staff that reflect the mosaic of cultures and backgrounds in the world. Throughout my coursework, I have had teaching assistants, professors, and advisers from backgrounds both similar to and different from my personal background. This has a tremendous impact on the overall campus culture. Having fellow classmates who can share in both the triumphs and trials of navigating a less-traveled career path provides an aspect of community. Professors and campus leaders encourage us to remain open to other's beliefs and opinions, which cultivates an atmosphere of universal acceptance. In my courses, I feel comfortable contributing to classroom activities and discussions without fear of being judged. I commend the university leadership for promoting safe spaces both inside and outside of the classroom. Intercultural engagement has been a strong component of my academic and extracurricular university experience.

In summary, my transition to university life has exposed me to new cultures and ideas that have broadened my social awareness. This opportunity for exposure has been reciprocated, as I have also had the great opportunity to share my experiences with others. Having a shared understanding and openness among classmates, advisers, and professors sets the atmosphere of acceptance. This positive experience creates an environment in which each student feels welcome. We each hold the responsibility for promoting a climate of care, respect, and honor for each other in our unity and our diversity. 


\section{The Golden Ticket}

\section{Shelly Brown-Jeffy}

A college education is often touted as the golden ticket to upward mobility and great career opportunities. The wealth of career options that once required only a high school diploma have been replaced with those that require a bachelor's or advanced degree. High school graduates enter college to fulfill their aspiration of upward mobility. Many of these college enrollees, however, are the first in the family to attain higher education.

College students who are the first in their family to attend an institution of higher education are considered first-generation college students. First-generation college students begin school without cultural capital (the accumulation of knowledge from parents who have attended college). Parents who have attended college can transmit information about what is expected of their children while they are in college and how to engage with professors. Children of college-educated parents acquire traditions that often translate into the academic and social skills necessary for academic success. They are more likely to know and understand the expectations of their instructors and appropriate responses to those expectations.
Because first-generation college students have not been socialized into the college academic process, they are less likely to have access to such knowledge and skills that can contribute to their success. First-generation college students may not possess the language commonly used by many college professors. Since first-generation college students are less likely to communicate with faculty outside of the classroom, the limited communication leads to fewer opportunities to assist faculty with research projects. Faculty can involve first-generation students in their research by actively reaching out to these students and initiating dialogue.

(1) My challenge. No one in my immediate family had attended college. Although obtaining my undergraduate degree was fairly easy, graduate school was a challenge. I completed my undergraduate degree at a historically black university (HBCU) that traditionally educated first-generation students. The professors at the HBCU were well aware that most of their students needed assistance in navigating their educational career. At this HBCU, professors pushed me toward opportunities that were unknown to me. Graduate school was more difficult, as I was one of the few in my cohort without highly educated parents. When given my first opportunity to conduct research with a professor, I had no idea how to begin. My professor simply said, "Here is my data set that you can use to work with." Although this particular instructor may have believed that the offer had been extended to engage in research, I needed more than just an invitation to use a dataset, because I had no idea what to do. I later worked with a professor who asked me to become involved in her project and carefully detailed the tasks needed for the project. These college experiences have been my guide for interaction with students.

(2) Myresponse. One of the biggest challenges to conducting research with students is identifying those students who are ready, willing, and able to engage in research. Sometimes professors will post that they are looking for someone to work as a re- 
search assistant or take on a similar role for a project. Some institutions have undergraduate research awards for students who engage in some type of research with a professor. Often, however, first-generation students do not reach out to participate in such options without a little coaxing. As a research mentor, it is my job to help students find and apply for such opportunities to engage in research.

First-generation students who have not yet been socialized into the student role may not be aware of opportunities to work with faculty or of the benefits of engaging in research with faculty members. These students may not have noticed the public call for a research assistant (if one was made) or know that it is possible or even appropriate to ask a professor about research opportunities. For research mentors, it is important to identify, request, and develop student researchers, especially among first-generation students who may not start the conversation. I actively invite students to engage in research projects because I know that students may not approach me about my work.

I begin research mentorship by thinking about the skills possessed by my students and developing ways for students to use and enhance those skills throughout the research process. It takes a while for students to be able to formulate a research question that can be addressed. Thus, I do not expect my students to have all the answers when I begin working with them. I think about engaging in research with students as a process instead of focusing on an end result. Although academia trains us to think about research in terms of the finished project (such as a published article), research mentorship is a process; students learn as much with the process of research as they do from the end results.

I begin the research mentorship process by giving students a brief summary of my current project and asking them if the topic sounds interesting to them. If a student expresses interest in the project, we discuss what aspects of the project interest them. Sometimes students are simply interested in the topic in general, sometimes students are interested in the method, and sometimes students are purely interested in a course grade. Once I know a student is interested in the process, I often provide some background information that typically includes a brief article to read.

Students who are most interested in the general topic of the research usually work to review the literature on the topic. In a meeting, the student and I will discuss key terms that are important to the topic and select the databases that are to be explored. Students are given a log where they record the key terms and search engines that they use. The log is used to remind students that they need to systematically and methodologically follow a process while reviewing the literature. The students also compile a bibliographic reference list that includes article abstracts or book summaries. The main goal of the abstract process is to help students understand that the process of systematic review is a necessary first step for all research projects.

Students who are more interested in the methodology of research are often asked to assist with the development of an instrument that can be used with pre-pilot data and pilot data assessment. When the topic and methodology of the research project has been determined before student involvement, I ask students what they feel is missing and needs to be added to the assessment instrument. Through a series of meetings, students are involved in the process of building the assessment instrument. Throughout this process, students must focus on understanding the parameters of budget constraints, time constraints, and the sample population. These research meetings result in some of the most fun and engaging research mentoring conversations. My students feel heard and valued because their suggestions are incorporated, and they learn that collaborations are important because no one person has all of the answers in a research project.

As a research mentor, I am least likely to ask a student to collect data for a research project. Although students can learn about research by collecting data, I 
find that asking students to only collect research data is treating them more as a student worker than as a research collaborator. My goal as a research mentor is to develop young researchers and not use students to complete my own research.

(3) What I have learned. I have learned that thinking about research mentorship as a process enhances the research experience for my students and me. These young researchers bring a unique way of looking at research because they have not been constrained by the rules. They have a raw curiosity; a way of thinking that may not have been formalized. Helping students see the value in the process of research helps their personal growth and personal career goals.

\section{"...Research mentorship is a process; students learn as much with the process of research as they do from the end results."}




\section{My STEM Family}

Jarvia Meggett

I entered the TRIO McNair program at the University of South Carolina with no experience in research, not fully understanding what was expected of me or what research really involved. I was afraid of my possibilities for success in the program. I thought the program would be challenging and unwelcoming to a young, African American female like myself, because a lot of my professors did not really look like me.

When I began working with the TRIO McNair program, I realized the climate was different than I anticipated. The director of the TRIO program was an African American female who gave me the first sense of hope that I could actually conduct research. Thus I immediately was introduced to someone who looked like me and could relate to some of the struggles that I face daily. She was very open and "real" about what the experience would be like. She also emphasized that she would be there with my fellow program participants and me every step of the way to ensure our success. I immediately knew that I had a supporter in her.

The first time I met my cohort members, we did a few bonding activities. The activities really helped us to learn about each other's backgrounds, struggles, strengths, weaknesses, and goals. We instantly connected, became a family, and are still a family to this day. I talk to some cohort members almost every day, and we often text each other and spend time together. We became each other's support system so that each of us could reach our goals. We laughed together, cried together, and experienced each other's hardships. We became one. I think this is what really made me enjoy the program.

Later during the first week of the program, we were introduced to our mentors. I thought this experience would be overwhelming, because these were people with $\mathrm{PhDs}$ who have conducted lots of research and done such great things. I wasn't sure if they could relate to me. I was definitely wrong. My mentor was so welcoming and down to earth. She didn't brag about all of her experiences. She was just interested in knowing about me, my interests, and how she could help in meeting my goals. She asked questions to help me dissect different issues of my interests. One of the things I remember most from our meeting and really helped us to build rapport was her body language. She wore a smile, and I could just see her happiness and excitement during the entire time of our talk. It made me want to talk to her more. Because of her welcoming spirit, I felt comfortable sending her emails, requesting meetings, and asking for letters of recommendations and other things. Even when she gave feedback on my research as I progressed through the program, she did it in such a pleasant and informative way that I could tell that she really cared, and it made me more receptive to her feedback.

I think the McNair program has a very welcoming climate. One common thing I've heard throughout the years of working with other cohorts is that the faculty and staff of the program is really welcoming and make the students feel like they were family. They actually take the time to build relationships with the students, sharing their stories, their struggles, and their ways of overcoming struggles. This building of rapport is vital because they show us that they're human also; they went through things, but they still were able to reach their goals. It gives us motivation. It also makes us feel welcome to seek their advice about things we may be going through. 
"Just because we have

commonalities doesn't mean there is inclusivity."
I feel a lot of people assume that, because people are the same race, gender, ethnicity, etc., it results in an inclusive climate. However, I believe that is the furthest thing from the truth. Just because we have commonalities doesn't mean there is inclusivity. I think inclusivity has to be achieved through relationship building and understanding of people. Everyone isn't the same; even within cultures there are differences. I believe, in order to have an inclusive climate, people first have to recognize that differences do exist. Trying to put everyone under one umbrella ruins inclusivity. 


\section{Chutes and Ladders}

\section{Claudia Benitez-Nelson}

No student is the same. Each has their own strengths and weaknesses that makes their potential contributions to science and technology all the more innovative and exciting. However, life is often a game of chutes and ladders, with high and lows that seem to appear by chance. After years of trial and error, I have learned some surprising lessons about how to help students-particularly students of color-transition into and out of their undergraduate and graduate degree programs.

For most students, the biggest hurdle is asking for help. Faculty members often expect students to seek help when they need it-but for students of color, who often are the first in their families to attend college and/or are from lower socioeconomic backgrounds, simply knowing they can and should ask for help is a major step. I recently had a fourth-year undergraduate taking a very difficult Physical Chemistry course. As we chatted about the semester, she mentioned that she was not doing as well as she had hoped. I quickly discovered that she had not bought the required textbook because she could not afford it. Instead of asking me or her instructor about other options (buying a used copy, obtaining a loan from another faculty member, and so forth), she had spent hours at the library taking photos of every page in the book (nearly 300 total). When I asked why she had not sought help, she said she did not want to bother anyone. This reticence, even in fourth-year students, is pervasive and extends far beyond coursework. Such reserve is a fundamental barrier to increasing the number of underrepresented students who enroll in and complete graduate programs.

Students with undergraduate research experience have the advantage of working in an environment in which seeking assistance is both appropriate and expected. Faculty mentors and upper-level students provide more focused attention as undergraduates learn the steps of working through problems they encounter. Asking for help is not only wanted, but a requisite for success. This translates extremely well into graduate programs, where students who have participated in undergraduate research simply feel more comfortable in asking for help both in and out of the lab.

The next biggest hurdle for students occurs when they start conducting their own research, as there is often no easy answer.
Data are neither right nor wrong, but they always have a story to tell. Students frequently experience difficulty in deciphering that story. This shift in thinking is perhaps the biggest transition for many students new to research. Given these issues, it might be assumed that many underrepresented students might have a more difficult transition. This is simply not true. In fact, many of these students outshine their peers in this regard. They feel much more comfortable with the experimentation process and often challenge hypotheses through a unique viewpoint. Their work has resulted in groundbreaking research simply because they refused to accept poorly founded assumptions. Although it can be a challenge for underrepresented students to participate in undergraduate research due to financial constraints, lack of experience, and gaps in coursework, it is clear that these experiences are ladders to success and are critical for encouraging students to enter graduate school.

Consistent and active mentoring is also crucial. It is not enough to keep the office door open. Rather, faculty members must aggressively pursue and interact with underrep- 
resented students as early as possible in their academic careers. From financial hardship to a lack of familial support, these students encounter many chutes that make them feel as though they have fallen back to where they began. Finding individuals who can both help students as problems arise and assist them in developing a support network as they progress through their undergraduate and graduate careers is paramount. There are numerous programs available to nurture the success of underrepresented students in STEM. The key is helping them find, and above all, use the resources available to them.

The National Science Foundation-funded GeoScholar Scholarship Program at the University of South Carolina does just that. Students are provided with substantial financial and housing support as they pursue undergraduate degrees in the geosciences. All participants are required to stay in a living and learning community in the first year, expected to meet with me at least two times a semester for advising, strongly encouraged to apply to multiple research opportunities off campus,

\section{"...for students of color, who often are the first in their families to attend college and/or are from lower socioeconomic backgrounds, simply knowing they can and should ask for help is a major step."}

and placed in research labs as early as their first year with support from university-funded undergraduate research opportunities. Participation in the TRIO McNair Program serves as a boot camp for students who are interested in pursuing graduate degrees. The program includes summer research, faculty mentors, and GRE preparation.
The lack of minority students in graduate programs is often described as a "leaky pipeline." As instructors, we must build and hold the ladders to lift them up above the many chutes they will encounter. Continuous mentoring support is critical for helping every student reach their potential at the top of the board. 


\section{The Value of Building Personal Relationships}

\section{Paul L. Beasley}

As an undergraduate, I came to appreciate the value that my college, Earlham, placed on personal relationships. As a young African American coming from the segregated South, I was very aware of cultural differences and their potential impact on my ability to succeed. But a campus tradition that stemmed from the Quaker faith made that adjustment easier. Even today, all members of the Earlham community are addressed by their first names. Although I realized early that this tradition came with the expectation that I would rise to a higher level of interaction, it also had the effect of personalizing relationships, facilitating friendships, and removing personal barriers. I developed very strong relationships with noted scholars that I came to know not in formal settings or through their titles and publications but during coffee breaks and as members of a community.
Underrepresented minorities (URM), especially those who come from first-generation and low-income backgrounds (FGLI), face a significant challenge when crossing the cultural divide between their communities and higher education, especially at predominantly white institutions. This divide, with its racial and cultural differences, often makes it difficult for students to establish effective relationships with faculty. However, the value of these relationships for both students and faculty can be extremely rewarding to efforts that promote academic careers. The Ronald E. McNair Post-Baccalaureate Achievement Program at the University of South Carolina (one of the federal TRIO programs that focuses on graduate school and career success for low-income and minority students) supports faculty mentoring by facilitating relationships between faculty and students, and providing faculty with information on factors that can hinder these connections.
The orientation for McNair faculty research advisers includes a profile of FGLI students and an overview of strategies that often support their success. However, care is taken not to stereotype students and to give consideration to each student's academic background, research interest, and desire to participate in the program.

To address any institutional estrangement that students might feel, McNair faculty and staff define common goals and procedures that support a sense of community. Although students and faculty represent various fields of study, a common set of goals allows each cohort to be supportive of each other. For example, students present their research ideas in small groups and in a general assembly that includes faculty. For each presentation, faculty advisers require that they ask questions, offer suggestions, and be supportive of the presenters in general. Since the emphasis is the structure of good research, their diverse fields 
of study are assets to this goal. Students learn within the kind of close working relationships evident in most graduate programs.

As strong communities require personal relationships, faculty are encouraged to take a personal interest in students during mentoring meetings and other program activities. In addition, program staff arrange opportunities for faculty and students to interact in social settings so they can go beyond the business of the program to engage as friends. Signature events include an initial meeting over sandwiches for introductions, a visit to an ethnic restaurant after submission of the final research paper, and a cookout at the end of the summer.

One of the most daunting tasks for the program is demystifying the journey to an academic career. URM and FGLI students seldom have personal relationships with individuals who have completed doctoral degrees. Many will attribute this accomplishment to extraordinary intelligence and the unknown rather than background and experiences. Therefore, diverse faculty at the university ex- plain to students their individual paths to the PhD. Students are often amazed by the similarity between their experiences and those of their faculty. They also realize that hard work and determination are the deciding factors in academic success.

Similarly, students often have an exaggerated view of what it takes to conduct research. When discussing their paths to the $\mathrm{PhD}$, faculty also explain how they developed their research interests. They explain that, initially, knowing how is more important than what; that interests change; and that any topic of interest is a legitimate research concern. Students often think that their research interests are too personal to qualify as legitimate research, such as alcoholism because of a parent's affliction or AIDS because of the loss of a sibling. Faculty approval of these topics helps students to focus on the structure of good research rather than the legitimacy of their concerns.

But, evenwitha sense of community, acommon purpose, an understanding of the $\mathrm{PhD}$ journey, and an appreciation for the breadth

\section{"One of the most daunting tasks... is demystifying the journey to an academic career."}

of research ideas, the most important factor in the encouragement of URM and FGLI students to engage undergraduate research and pursue academic careers is their relationships with faculty. The best mentoring comes from believing in students on a personal level and maintaining interest beyond the job description. I attended graduate school on the advice of a friend at Earlham who happened to be one of my psychology professors. Armed with his confidence, I knew I could succeed. 


\section{Freedom and Responsibility}

\section{Aisha N. Conwell}

Before I started college, everyone seemed to be trying to help in my transition from high school to college. High school teachers, university recruiters, and even family and friends at the Thanksgiving dinner table had advice. All I asked my older cousin was to pass the mashed potatoes-not ask for an interrogation. Typically, they talked about similar topics: navigating campus, describing classes and professors, living in a campus residence hall, and so forth. College seemed to be in the distant future-not now. I expected everything to go as well as it had in high school. After all, my mother worked at the University of Kentucky as a student affairs counselor.

However, once I reached the university, everything became very real. Despite the lectures and general conversations on how to be successful and have a positive college experience, things begin to "fall through the cracks," and I found myself sitting in my nice, new dorm room wondering what had gone wrong.

I entered college with the idea that I would major in animal science, graduate in four years, and go to veterinary school as a graduate student. I would become an orthopedic surgeon for animals. But then I took chemistry, and my strength was tested. After failing the class in the spring and summer semesters, I realized that I couldn't do it. Mentally, I wasn't ready to take on the classes necessary to reach my goal. Luckily, I had other dreams, so I changed my major to English. Despite this positive change, part of me was still upset that I had failed. Although my family reassured me that things would work out okay, I still couldn't shake my heavy feeling of failure.

Over the fall semester, I became really depressed and began to skip classes, even the ones I enjoyed, and lost interest in going out with friends or leaving my bedroom in general. From the outside looking in, it was pretty obvious that something was wrong with me, but in my mind, I just chalked it up to laziness. Student counseling helped me to realize that what I was feeling had a name-depression. The more depressed I became, the more upset I became with myself, and the vicious cycle continued. By the time I finally sought help from the Counseling Center, it was too late to salvage the semester. With the help of my advisers, I dropped my courses for the semester but enrolled in the spring semester so that I could still possibly have a successful academic career with an acceptable GPA.

All of the conversations and lectures that I had about college and what to expect gave me a feeling of confidence that I was fully prepared for college. In my primary and secondary education, I had earned mostly As and Bs, even amid the demands of being a full-time student athlete. I didn't have to pass every test or do all of my homework to earn a passing grade in my classes. I didn't have to develop a relationship with my teachers because I saw them every day walking the same hallways as me. Nothing was really hard or challenged me to break out of my habit of procrastination, ignorance about good study practices, or simple lack of attention to grades.

The school system is designed to have plenty of safety nets for students so that if they fall, there was always a way to bounce back. This isn't a bad thing because it is showing that teachers are trying to move their students to the next level the best way that they can. However, I became too comfortable with these nets, and I always thought they would be there. So when it came time for me to go to college, this mentality of "everything will 
be okay" was still there, but the safety nets were not. Even after all of the information and advice on college life, the differences from high school, and the increased demands of college, I ignored them. My customary habits remained, and when things really started to worsen, I tried to fix them by doing nothing different.

I have learned that I am not alone. Many students have a bumpy transition from high school to college. It's not always going to be easy sailing once you get away from the structure that past schooling has provided. But it's okay to make mistakes and realize that maybe you don't have it together like you thought. Now is the time to make mistakes and learn from them. Alongside of the academics, college helps to shape you into the person that you will be for society. It hands you situations that are similar to what will happen in real life. Luckily, college is a more forgiving place, if you actually use your resources and don't try to fix things on your own.
My experience has taught me that sometimes you need to take a step back to figure out how to move forward, and it's okay to do so. My struggles began toward the end of my first year, but I simply tried to push through it on my own instead of seeking help. I was so worried about messing up my life and the plan that I had made for myself that I couldn't see that by trying to go on, I was making things worse. I would encourage other students to resist the pressure to graduate by the date set by the university or by the friends that entered college at the same time that they did. Students should map their college years and future career on their own terms. It can be hard to ignore the world around you and trust yourself when your path begins to wind differently than your peers, and you start to feel like a tortoise racing a hare, but we all know how that story ends. You need to reach the finish line on your own terms, or you might not be happy with the end result.
It's hard to be prepared for something you've never experienced before, so why would college be any different? Although college seems fun in movies and TV shows and presents a tempting picture of being free to do what you want, there is a lot that comes with it. You could almost say, to borrow a quote from Spiderman's Uncle Ben, "with great freedom comes great responsibility." My advice to other students would be to try to listen to all of the advice that people give. They do mean well. In my experience, their advice has been applicable in many situations, but I just applied it a little too late. Sometimes it takes getting up close and personal with something to realize that it will be a challenge, but it's important to never ignore your support system. Whether it is composed of all those people providing advice and/or trusted professors and advisers, rely on them for your advancement. They care about your well-being, and sometimes all it takes is a question to get all the help you need. You are not alone in your way of thinking, and it's to your benefit to be open to a change in the way you think. It's what college is all about. 


\section{Personal Responsibility}

\section{James N. MacLeod}

A student came to my laboratory for a summer research fellowship at the end of her first undergraduate year. In several ways, she was fairly typical of undergraduate students who study with my group-broad career interests in a biomedical field, reasonably good academic record in high school and college, and often fairly limited experience in a research laboratory. My group of summer students that year totaled five. They were all women and all full of promise. Academically, the other four students had more background in terms of college-level coursework; however, none of them arrived with substantial experience in a basic research laboratory or with discovery science.

Although this group was somewhat larger than the number of summer students that I have historically accepted, in recent years I have come to appreciate certain benefits to working with a group of four to six students. The general mentoring strategy had a few layers.

(1) First, a framework was set up in which the students could learn together as a small group, thereby fostering camara- derie and collegiality. It involved a shared research project where each student worked through a similar academic/research exercise but with individualized components. For the group this particular summer, each student was provided with the names of three specific genes. The assigned task was to find and summarize available bioinformatic information on those genes and the encoded proteins in public data repositories (databases). This was not a "sink or swim" process; didactic guidance was provided to the group and each student on how to get started and the scope of what was possible. Students were encouraged to work together and share successful strategies.

(2) The second layer was an individual research project. The students worked with and were mentored individually by a graduate or postdoctoral student in the lab. They had an individual research topic in the context of the group, but that topic was connected to an established area of study within the laboratory.
(3) The third layer was daily small-group discussions that lasted 1-2 hours. Topics represented foundation knowledge in my laboratory's areas of interest and were led either by one of my graduate/postdoctoral students or me. Normally, these sessions were structured in a "journal club" format in which the paper might be a review article or textbook chapter. On other days, these same graduate/postdoctoral students or a lab visitor might provide overviews and lead discussions on their individual research projects. Finally, the students each lead two sessions-a journal club session focusing on a paper relevant to their individual project and a presentation at the end of the summer on their results/findings.

The first-year student was always a bit quiet, but I honestly did not realize that she was having serious difficulties until about two-thirds of the summer was over. By the last couple of weeks, however, she was clearly struggling. She remained cordial, and I never perceived any outward friction, but her summer fellowship ended with no energy or forward-think- 
ing motivation. Summer students who have a positive experience frequently want to talk about "where can I go from here?" or "what opportunities might be possible going forward?", wishing to learn about other projects in my laboratory or broader educational programs and career choices. For this student, however, there was no expression of interest along these lines.

Considering the student's experience. In reflecting on the student's struggles, it seems constructive to attempt an honest consideration of observed differences. I am not sure if these variables were associated or are relevant to her challenges, but they were present.

(1) The student was just finishing her first year in college, whereas the other summer students were upper-level undergraduates.

(2) The student elected to enroll in a summer course, which met every day. The class was general chemistry, which can be an academically challenging topic for many students. None of the other students had a similar competing commitment.

(3) The student was African American. Personnel in my laboratory certainly have unique aspects to their identity, with four different nationalities represented and one openly gay person, but there were no other individuals of African ancestry that summer.
(4) The student's demeanor, at least in the context of my laboratory, was somewhat quiet, perhaps leaning a bit to the introverted side of the personality spectrum, and somewhat lacking in self-confidence.

(5) Finally, the student seemed passive, especially in comparison to others in my laboratory. She was not openly self-driven or eager for opportunities. She was pleasant and accepting, but passive.

Reflecting on these variables. In considering the five variables, the following thoughts are my personal perspectives and highly subjective.

(Variables 1 and 4). The reality that this student was slightly younger, with less academic background and a more introverted personality may have relevance in a couple of ways. Was she lost at times, but I failed to pick up on it or appreciate the extent of her struggles? I shared some early concern with a senior postdoctoral student who was co-mentoring the student with me. That said, we both failed to make constructive adjustments.

(Variable 2). I think the student's enrollment in a challenging summer course may have been a substantive variable. We consciously gave her time and space to "study" chemistry, which she seemed to be doing. Beyond the two hours each day in class, she frequently spent time at her lab bench reviewing class material and working on chemistry problems. This may well have further impacted her ability to benefit from laboratory research opportunities provided by the fellowship, as well as her ability to keep up with the group in general. In other words, perhaps the chemistry class and the research fellowship together proved to be too much for this student. She was unable to multitask to the detriment of both efforts.

(Variable 3). I truly hope that the student's ethnic background was not a variable. From my perspective, it did not seem to be. Cultural, religious, ethnic, and other areas of human diversity will occasionally come up informally in lab conversations, but from my perspective, it always seems healthy and in the spirit of understanding/appreciating differences rather than representing any type of judgment. That said, I am a white male and grew up with privilege. As such, although sincerely upset by the extent and impact of continuing racism and prejudices in our society, I am admittedly naive in the sense of having not personally "walked in the shoes" of an African American.

(Variable 5). Personal drive is a variable that I rank high in relevance and importance for all students. Are students "hungry" for opportunities and self-motivated, or passive and reactive? Do they strive to open doors and find their path, or do they wait for someone to suggest or even tell them what to do? Do they ask questions, reach for more information, and follow through? My perception is that these qualities usually improve as a student matures and develops a level of self-confidence. I do not think it is a function of where a person falls on the introverted-extroverted personality spectrum. From my perspective, this personal drive and self-motivation failed to engage for the student in the context of her 
"Was she lost at times, but I failed to pick up on it or appreciate the extent of her struggles?" summer in my laboratory. I am sure the reasons are multifactorial and include failings in my mentorship and/or the structure of the summer program in my laboratory.

Looking forward, providing experiential educational opportunities needs to be successfully coupled with empowering a sense of ownership and personal responsibility in students for their path forward. One does not succeed without the other-they are codependent. 


\section{Sometimes Structures Are}

\section{Not Enough}

\section{Bessie Guerrant}

The University of Kentucky (UK) has emerged from a segregated past that once totally excluded African Americans, now embracing the contributions of a diverse learning environment. The institution affirmed a goal to increase diversity in the 2003-2006 Strategic Plan: The Dream \& the Challenge. The university adopted a goal that it would nurture diversity of thought, culture, gender, and ethnicity. The goal required that UK improve the climate for diversity by creating a diverse workplace and learning community. During this time, one of my research programs was designed to increase the number of students of color who were mentored by research faculty. Several offices and programs set out to address this goal.

As a female, mid-level administrator of African American descent, I feel very strongly about developing and managing inclusive programs for all students but especially students of color. But, through 25 years of expe- rience, I have learned that this is no easy feat, especially at a large, research-intensive institution with a majority population of white students and faculty members. For years, the university has worked to address issues related to recruitment, retention, and graduation of students of color by providing academic, social, and cultural programs. Two programs developed in my office targets underrepresented students in research-the Kentucky Young Researchers Program (KYRP) for 11th and 12th graders, and the Bucks for Brains Summer Research Program for UK undergraduates.

Two years ago, I was approached by a mother of a high school student who had a lifelong dream of becoming a veterinarian. The mother wanted her daughter to participate in my high school research program and be mentored by a UK professor in veterinary science. The student was a beautiful, "dark skinned” African American. She earned excel- lent grades, excelled in three sports, and had a record of success in a pre-veterinary certificate program. She seemed very confident that she could pursue such a major at the university's College of Agriculture. She was not aware of the different environment that college would involve and of the need for assistance from both her peers and student affairs professionals to be successful in her major.

I had a professor in mind to serve as her mentor. The professor had mentored many undergraduate students (albeit not minority students) for several years, and I considered him a wonderful mentor. This white male professor of veterinary science was excited to meet an African American student interested in veterinary science. He had never had such a student in his classes or lab. They decided mutually to start the research in the summer. Summer arrived, and the student became so involved in the summer orientation program for first-year students that, together, the 


\section{"In general, African American students face numerous barriers in their academic career-development} process."

student and the mentor decided to further postpone the research in the lab. The student managed the bridge program very well, finishing the summer with a 3.9 GPA for introductory coursework and study activities.

During the fall, the student maintained a strong GPA. During the second semester, however, she was failing her chemistry exams. She had never experienced such a challenge in her academic career. Student support staff in academic affairs was not aware of her problems, as she did not tell anyone of her struggles. She did not attend the tutoring sessions offered by the Center for Academic Resources and Enrichment Services (CARES), in which she was enrolled and required to attend. She failed the chemistry course, and her adviser encouraged her to retake the chemistry class during the summer. However, the summer was slated for research with her mentor. I did not know that she was struggling with fear of failure due to her performance in the chemistry class, resulting in a loss of confidence in her learning abilities. I only learned of the difficulties when the professor gave me a report of his concerns about the student, and the student's mother told me that the student also had failed the summer chemistry class. I later learned from the student's advisers that she was absent from tutoring sessions and chemistry study groups and had not talked to her chemistry professor. She withdrew from everything. By fall, she had stopped attending classes, remaining in bed in her residence hall room.
In general, African American students face numerous barriers in their academic career-development process. Too often, they have inadequate knowledge of the options available to help them. It is not uncommon for students to enroll at the university and discover after the first year that they may not be academically competitive for admission into the major due to poor grades. They may be underprepared for the academic rigor of their chosen major or lack the appropriate knowledge of the major's academic requirements. Also, students often lack knowledge of how to utilize faculty and staff members to assist them when they encounter trouble in the transition from high school to college.

Working with the student, the mentor, the mother, and the CARES counselor, I discovered that sometimes all our intentions, time, and efforts are not enough. Our public schools may do an adequate job of preparing students for college, but there is still much that students-especially underrepresented students-need to be successful at large research institutions like the University of Kentucky. 


\section{It Is Not Rocket Science}

\section{Sandra Gregerman}

I recently stepped down as director of the Undergraduate Research Opportunity Program at the University of Michigan after a 25-year tenure. The goal of the program was, and still is, to use undergraduate research as a vehicle for the successful transition of diverse students to the university through the creation of faculty/student research partnerships beginning in the first year.

During my tenure, I worked with countless first-and second-year students and community college students from diverse backgrounds to involve them in research on campus in all fields and disciplines. Along the way, I learned a great deal about the biases and assumptions made by faculty about students-what they bring to campus, what they should instinctively know, how a student's affect can be confused for lack of interest, how many faculty only welcome into their research the brave and privileged student who knocks on their door and has the or social capital to do so. I also learned that we could level the playing field for those students who are first generation and do not feel welcome on campus with our messaging and the most basic preparation. I also learned that faculty needed to be educated to embrace a new idea about who should have access to research on campus and why they should open their doors to a different group of students.

When the program began, it was clear that faculty would not engage first- and second-year students in research unless some training and preparation were provided. Although at first this preparation was conceived as relating only to acquiring the content and technical skills needed to do research, it became more to do with helping students understand the culture and norms of the academy, gain confidence in their abilities, know that they would be welcomed by the faculty, and understand how research would benefit their academic and professional success. This preparation was as simple as teaching students how to address faculty properly in writing professional emails, prepare for interviews, ask good questions, and articulate their interest in a particular project or area of research. Sometimes it involved helping students reflect on how their unique perspective and experiences would benefit a project. At other times, it involved helping shy and introverted students practice showing excitement and enthusiasm when their demeanor was misinterpreted as a lack of interest or competence.

Preparation also involved staff education. It was easy to make assumptions-for example, all students would see the value of participating in undergraduate research, all students would know that research is not confined to people planning academic careers but also applies to problems and issues that they care deeply about, and/or all students would understand that the mentorship they would experience would be invaluable at a large and impersonal research university. Preparing a student to find a good project that would engage them personally and intellectually was critical to the success of the program and the partnerships. Equally important was helping students find a good mentor and research environment that met their personal needs. Did they value independence, or were they seeking a more interactive mentor? Were there specific skills they wanted to gain from the experience? Did they have a personal story that motivated their interest and would be of benefit to them and the project? Helping students find their passion often means learning about 


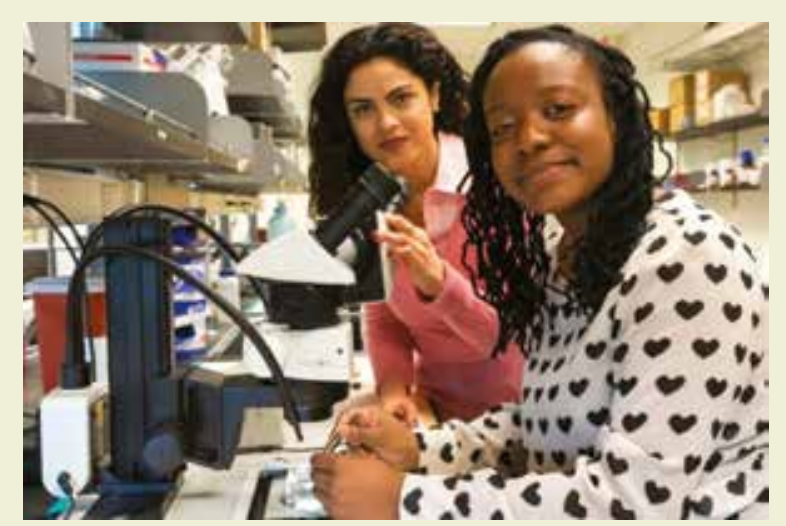

University of Michigan student Malika Malik (class of 2017), front, with her mentor, Ariella Shikanov, associate professor of biomedical engineering. Malik is now enrolled in the University of Michigan dental school.

their story. Students also needed to understand that the interview was as much about their interviewing the mentor as the mentor interviewing them.

To accomplish all of these tasks required structures and intensive work with each student as well as work with research mentors from the faculty. Students were assigned a peer adviser from a common academic background (biomedicine, humanities, engineering, social sciences, and so forth), who became acquainted with the student and learned about his or her interests, aspirations, and goals for engaging in research. The peer advisers helped students explore myriad projects that were open to first- and second-year students, shared their own searches for potential mentors and projects, reviewed the students' resumes, and conducted practice interviews with students. The peer advisers also shared their process for creating good mentor relationships, and mentors shared with students the qualities of a successful student researcher.

Concurrent work with faculty was conducted to help them see the value of early engagement of students in their research (these students might stay all four years and make significant contributions to their work), shared stories from colleagues about the rewards of working with diverse students and could benefit their research, and shared best practices about the elements of a good project and environment for students. Over the years faculty who embraced diversity found the experience very rewarding, students brought new perspectives to a project, and students from diverse backgrounds appreciated the opportunity and knew what it meant to work hard. Faculty began to realize that those who showed passion and enthusiasm and even some naiveté about the norms of the discipline were often better researchers than the honors student in their chemistry class who got the highest grade on the last exam. When faculty started asking for more community college students or complained that the undergraduate researchers were prepared so well that they couldn't tell the "bad" students from the "good" students, the program was a success.
Over the years, more specific research training was added to the program-a set of workshops that built research skills offered concurrently with participation in the projects. These workshops included basic laboratory math; how to keep a lab notebook; how to read and understand the peer-reviewed literature; and how to work with SPSS, Endnote, STATA, R-Programming, Matlab, etc. While students often learned these things in classes, it was not until they had to apply these skills to their research that they understood the why and how to use these tools. This enabled us to cast a wider net and get more faculty involved in the program.

Finally, the importance of creating good partnerships was a key discovery. Students shared their thoughts about the attributes of the best mentors, and faculty shared the qualities of the best student researchers. This knowledge informs how students can be best matched to projects, how mentors' skills can best be aligned with the needs of diverse students, and how potential mentors-tenured faculty, postdoctoral scholars, and graduate students-can be "trained." None of what has been learned is rocket science. Good research partnerships require two people to be interested in each other's stories and successes. It requires faculty to be willing to share their own vulnerabilities, challenges, and uncertainty. This can be as simple as mentors telling students that there are no stupid questions or that they once earned a $\mathrm{C}$ in chemistry to clearly articulating expectations to students and holding high expectations for them. For 
students, it can be helping them learn to ask those questions and to arrive ready to work hard and learn. It can be reaching out to diverse students to invite them into a program and remove barriers so they can participate (such as applying work study to meaningful research experiences so students can have time to conduct research). It can be sharing with students how much faculty appreciate the work ethic of students from a community college or a first-generation background. It can be sharing success stories of students with similar experiences. It can be a faculty mentor who takes a minute to ask about a student's progress in classes, to invite a student to a talk in a department, or to introduce a student to colleagues. For students, finding just the right mentor and project can be life-changing for those who feel marginalized in the classroom.

The work done has changed the culture, for the most part, at the University of Michigan.
Early engagement is the norm. Thousands of students who would not have had this opportunity in the past now thrive in research activities across campus, have continued on to graduate and professional schools, and become successful in their careers. Students who struggled in their introductory classes were retained and are succeeding in fields they might have never discovered-from earth and data science to museum studies and ethnomusicology. Students who failed Introduction to Statistics have gone on to write quantitative dissertations and become faculty members. Perhaps most important, most faculty have realized that the old paradigm that students should knock on their door if they want to become involved in research is a sure way to prevent women and diverse students to finding their way into research and their disciplines.

\section{"Good research partnerships require two people to be interested in each other's stories and successes."}




\section{Further Reading}

Boysen, Guy A., and David L. Vogel. 2009. Bias in the Classroom: Types, Frequencies, and Responses. Teaching of Psychology, 36(1): 12-17. doi: 10.1080/00986280802529038

Chang, Mitchell J., M. Kevin Eagan, Monica H. Lin, and Sylvia Hurtado. 2011. Considering the Impact of Racial Stigmas and Science Identity: Persistence among Biomedical and Behavioral Science Aspirants. Higher Education 82: 564-596. doi: 10.1353/ jhe.2011.0030

Chemers, Martin M., Eileen L. Zurbriggen, Moin Syed, Barbara K. Goza, and Steve Bearman. 2011. The Role of Efficacy and Identity in Science Career Commitment among Underrepresented Minority Students. Journal of Social Issues 67: 469-491. doi: 10.1111/j.1540-4560.2011.01710.x

Hall, Donna M., Amanda Curtin-Soydan, and Dorian A. Canelas. 2014. The Science Advancement through Group Engagement Program: Leveling the Playing Field and Increasing Retention in Science. Journal of Chemical Education 91(1): 37-47.
Hrabowski, Freeman A. III, and Kenneth I. Maton. 2009. Change Institutional Culture, and You Change Who Goes into Science. Academe 95(3). https://www.aaup.org/ article/change-institutional-culture-and-youchange-who-goes-science\#.W0y3y7onaM8

Jackson, Dimitra Lynette, and Frankie Santos Laanan. 2011. The Role of Community Colleges in Educating Women in Science and Engineering. New Directions for Institutional Research 152: 39-49. doi: 10.1002/ir.407

Jones, Melanie T., Amy E. L. Barlow, and Merna Villarejo. 2010. Importance of Undergraduate Research for Minority Persistence and Achievements in Biology. Journal of Higher Education 81(1): 82-115. doi: 10.1080/00221546.2010.11778971

Killpack, T. L., and L. C. Melón. 2016. Toward Inclusive STEM Classrooms: What Personal Role Do Faculty Play? CBE-Life Science Education 15(3): 1-9. doi: 10.1187/cbe.16-010020
Marquez Kiyama, Judy, and Sandra Guillen Luca. 2014. Structured Opportunities: Exploring the Social and Academic Benefits for Peer Mentors in Retention Programs. Journal of College Student Retention 15: 489-514.

Ong, Maria, Carol Wright, Lorelle L. Espinosa, and Gary Orfield. 2011. Inside the Double Bind: A Synthesis of Empirical Research on Undergraduate and Graduate Women of Color in Science, Technology, Engineering, and Mathematics. Harvard Educationa Review 81: 172-209.

Packard, Becky Wai-Ling. 2016. Successful STEM Mentoring Initiatives for Underrepresented Students: A Research-Based Guide for Faculty and Administrators. Sterling, VA: Stylus.

Ross, Howard J. 2014. Everyday Bias: Identifying and Navigating Unconscious Judgments in Our Daily Lives. Lanham, MD: Rowman and Littlefield.

Steele, Claude. 2011. Whistling Vivaldi: How Stereotypes Affect Us and What We Can Do. New York: Norton. 


\section{About the Authors} and Editors

Paul L. Beasley retired in 2017 after leading the University of South Carolina's TRIO programs office for 29 years. He serves on the advisory board for the Pell Institute for the Study of Higher Education and the faculty for the graduate certificate program offered by the Council for Opportunity in Education and Colorado State University. He holds a doctorate in higher education administration from the University of Tennessee.

Claudia Benitez-Nelson is Distinguished Professor and associate dean for instruction, community engagement, and research at the University of South Carolina. Her research interests include particle formation, composition, and the flux of particles from the surface ocean to the seafloor. She holds BS degrees in chemistry and oceanography from the University of Washington and a PhD in oceanography from the MIT/Woods Hole joint program.
Shelly Brown-Jeffy is associate professor of sociology at the University of North Carolina at Greensboro. Her research interests include social inequalities, sociology of education, and race and ethnic relations. She earned her $\mathrm{PhD}$ from the University of Michigan.

C. Brooke Bruthers is senior program manager, Diversity Programs, at the American Physiological Society in Rockville, Maryland. She manages the awards, fellowships, and programs of APS that are aimed at broadening participation in the physiological sciences. She holds a BA from West Virginia University.

Michelle Carnicle is an undergraduate student majoring in biology at the University of Minnesota, Morris.

Niccole Villa Cerveny is residential faculty in the Geoscience \& Sustainability Programs at Mesa Community College. She holds MS and $\mathrm{PhD}$ degrees in geography from Arizona State University.
Amy L. Chang is director, education of the American Society for Microbiology in Washington, DC. Active in the promotion of mentoring of underrepresented students in biomedicine, she is a Fellow of the American Association for the Advancement of Science.

Aisha N. Conwell is an undergraduate student majoring in English at the University of Kentucky.

James Cotter is professor in the Geology Program at the University of Minnesota, Morris. His research interests include glacial geology, glacial sedimentology, and quaternary studies. He holds a BS from Franklin and Marshall College as well as an MS and a PhD from Lehigh University.

Mary L. Crowe is associate provost for experiential education at Florida Southern College in Lakeland, Florida, and is a principal investigator on the National Science Foundation Integrative Organismal Systems (NSF IOS) grant. She served as 2012-2013 CUR presi- 
dent and is a member of CUR's Diversity and Inclusion Task Force. Crowe previously was the director of the Office of Undergraduate Research at the University of North Carolina at Greensboro.

Lauren Dorn is an undergraduate majoring in biology at University of North Carolina at Greensboro.

Angelica Rose Galvan is an undergraduate student in materials science and engineering at the University of Michigan.

Monica Gerber is an undergraduate student majoring in biotechnology and minoring in premedicine, medical Spanish, and honors interdisciplinary studies at James Madison University.

Esther Goldthwaite is a student at Mesa Community College in Mesa, Arizona.

Joseph L. Graves Jr. is professor of nanoengineering and associate dean for research at North Carolina A\&T State University. His research interests include the evolutionary genomics of adaptation and biological concepts of race in humans. A Fellow of AAAS, he earned his $\mathrm{AB}$ in biology from Oberlin College; his MS in biological sciences from the University of Massachusetts Lowell; and his $\mathrm{PhD}$ in environmental, evolutionary, and systematic biology from Wayne State University.
Sandra Gregerman is special counsel on undergraduate research and student access at the University of Michigan, Ann Arbor, and former director of the university's Undergraduate Research Opportunity Center. Selected as a 2018 CUR Fellow, she was a founding member of CUR's Undergraduate Research Programs Division. Gregerman also served as a board member for the National Conference on Undergraduate Research.

Bessie Guerrant is director of the Office of Research Assessment and Student Research Programs at the University of Kentucky, a CUR Councilor, and a member of CUR's Diversity and Inclusion Task Force. She is a former Kentucky Distinguished Educator and director of Equity for the Kentucky Partnership for Reform Initiatives in Science and Mathematics (PRISM) Initiative. Guerrant was a member of the NSF/Statewide Systemic Initiative Equity Forum Committee and the NSF/Statewide Systemic Initiative Forum Planning Committee. She holds BA and MEd degrees from Smith College.

Thomas B. Higgins is a professor of chemistry at Harold Washington College, one of the City Colleges of Chicago. He served as a Councilor in the CUR Chemistry Division from 2012 to 2015 and was a rotating program officer in the Division of Undergraduate Education of the National Science Foundation from August 2015 to August 2017.
Anastasia Lin is associate professor of English and assistant vice president of research \& engagement at the University of North Georgia. Her research interests include Asian American poetry, literary cartography, multi-ethnic literature, and orientalism. She earned a BA in English and BS in chemistry from Wofford College, and earned her PhD at the University of Georgia.

Jena Lipham graduated from University of Minnesota, Morris with a degree in communication, media, and rhetoric in 2018.

James N. MacLeod is the John S. and Elizabeth A. Knight Chair and a professor of veterinary science at the University of Kentucky. His research interests include musculoskeletal sciences, genetics, and genomics. He holds a BS in animal science from the University of Delaware, and a doctorate of veterinary medicine (VMD) and $\mathrm{PhD}$ in pathology from the University of Pennsylvania.

Chryssa Michelle Maloney is a tutor in the Department of Academic Support Services of Harold Washington College, one of the City Colleges of Chicago.

Joshua McCausland is a PhD candidate in biophysics at Johns Hopkins University. He holds a BS in biology from the University of North Georgia. 
Jarvia Meggett is a master of science in nursing candidate at Johns Hopkins University. She earned an MPH degree from the University of Michigan and a bachelor's degree from the University of South Carolina.

Michael Newsom is a lecturer at Harold Washington College, one of the City Colleges of Chicago, who is dedicated to teaching in Chicago.

Kendell M. Pawelec is a research fellow in the Department of Mechanical Engineering at University of Michigan. Her research interests include nerve regeneration and biomaterials. She holds a BS in materials science and engineering from Michigan State University and $\mathrm{PhD}$ in materials science and metallurgy from Pembroke College, Cambridge University.

Nicola Plowes is residential faculty in the Life Science Department at Mesa Community College. Her research interests focus on the behavioral ecology of social insects, specifically of ants. Recent projects have included chemical ecology, cognition, navigation, territoriality, and self-organization. She earned a BS in biology (ecology, evolution, and conservation) from the University of Texas at Austin and a $\mathrm{PhD}$ in entomology from the University of Connecticut, and previously was a postdoctoral researcher at Arizona State University.
Crystal Scott is an adjunct faculty member in the Department of Biological Sciences at Boise State University. She also has taught at the College of Idaho and James Madison University.

Miriam Segura-Totten is professor in the Biology Department and Harry B. Forester Eminent Scholars Chair at the University of North Georgia. Her research interests include cell biology, molecular biology, and the scholarship of teaching and learning. She holds an $A B$ in molecular biology from Princeton University and a PhD in biochemistry, cell biology, and molecular biology from Johns Hopkins University.

Louise Temple is a professor in the Department of Integrated Science and Technology at James Madison University. Her research interests include bacterial pathogenesis, as well as bacterial virus discovery and genomic analysis. She earned a BS in biology and chemistry from Mississippi College, an MS in chemistry from Louisiana Tech University, and a $\mathrm{PhD}$ in microbiology and immunology from Medical College of Virginia. 
Mentoring through the Transitions: Voices on the Verge highlights individuals, programs, and institutions succeeding in assisting STEM students through critical junctures such as high school to college, community college to fouryear institution, and four-year institution to graduate school and beyond. It features the authentic voices of those who have participated in or built inclusive, supportive environments for all. 